\title{
Covid-19 Sürecinde Kimya Öğretmenlerinin Derslerinde Deneysel Çalışmalara Yer Verme Durumunun İncelenmesi
}

\author{
Examination of Chemistry Teachers' Inclusion of Experimental Studies in their Teachings in \\ the Covid-19 Pandemic
}

\section{Canan NAKIBBOĞLU ${ }^{1}$}

${ }^{1}$ Prof. Dr. Balıkesir Üniversitesi, Matematik ve Fen Bilimleri Eğitimi Bölümü,

nakiboglu2002@yahoo.com, (iD)000-0002-7292-9690

\begin{tabular}{l} 
Araştırma makalesi/ Research Article \\
$\begin{array}{l}\text { Geliş: 2021-10-21 } \\
\text { Atıf/ Citation }\end{array}$ \\
Nakiboğlu, C. (2021). Covid-19 sürecinde kimya öğretmenlerinin derslerinde deneysel çalışmalara \\
yer verme durumunun incelenmesi. Maarif Mektepleri Uluslararası Eğitim Bilimleri Dergisi, 5(2), 115- \\
142. https://doi.org/10.46762/mamulebd.1013257 \\
Nakiboğlu, C. (2021). Examination of chemistry teachers' inclusion of experimental studies in their \\
teachings in the covid-19 pandemic. Maarif Mektepleri International Journal of Educational Sciences, \\
5(2), 115-142. https://doi.org/10.46762/mamulebd.1013257 \\
\hline
\end{tabular}

Öz

$\mathrm{Bu}$ çalışmada, kimya öğretmenlerinin Covid-19 sürecinde derslerinde deneysel çalışmalara yer verip vermedikleri ve yer verilmediyse bunun nedenlerinin derinlemesine incelenmesi amaçlanmıştır. Bu amaçla çalışma nitel araştırma desenlerinden durum çalışması desenine göre yürütülmüştür. Türkiye'nin farklı illerinde görev yapan 36 kadın ve 11 erkek olmak üzere toplam 47 kimya öğretmeni kolay ulaşılabilir örnekleme yoluyla çalışmaya dahil edilmişlerdir. Çalışmada veri toplamak üzere geliştirilen bir Google form veri toplama aracı olarak kullanılmış ve veri analizi içerik analizi ile gerçekleştirilmiştir. Çalışma grubunda yer alan öğretmenlerin \%64'ünün uzaktan eğitim sürecinde deneysel çalışmaya derslerinde yer vermedikleri ve bu duruma ortam uygunsuzluğu, öğrenci odaklı, program odaklı, sinav odaklı, kişisel ve teknik nedenler olmak üzere altı neden ileri sürdükleri belirlenmiştir. Öğretmenlerin \%72'sinin OGM materyal sitesinde yer alan etkileşimli deney videolarından haberdar oldukları belirlenirken, kimya öğretmenlerinin \%66'sının bu deney videolarını inceledikleri görülmüştür. Deneyleri inceleyen 31 öğretmenden 26'sı videoları yararlı, öğrenci seviyesine uygun ve öğrenmeye katkı sağlayabilecek olduğunu belirtirken beş öğretmenin 
videoların sayısal anlamda yetersiz olduğunu düşündüğü sonucuna ulaşılmıştır. Çalışmada ulaşılan diğer bir sonuç, çalışmaya katılan kimya öğretmenlerinin büyük bir kısmının uzaktan eğitim sürecinde deneysel çalışmaları derslerde nasıl kullanacaklarına yönelik bir eğitim almak istedikleri şeklindedir. Çalışma sonunda kimya öğretmenleri için bu tür bir eğitimin nasıl olması gerektiği konusunda ve kimya öğretmen yetiştirilmesine yönelik önerilere yer verilmiştir. Böylece çalışma sonuçları, hem olası bir uzaktan eğitim planlaması durumunda deneysel çalışmalar konusunda neler yapılabileceği hem de laboratuvar imkânı olmayan okullarda görev yapan öğretmenlere yol gösterici olacağı öngörülmektedir.

Anahtar Kelimeler: Covid-19, kimya öğretmeni, deneysel çalışma.

\section{Abstract}

This study aimed to examine in-depth whether chemistry teachers include experimental studies in their classes during the Covid-19 process and if not, the reasons for this. For this purpose, the study was carried out according to the case study pattern, one of the qualitative research designs. A total of 47 chemistry teachers, 36 female and 11 male, working in different provinces of Turkey, were included in the study through easily accessible sampling. A Google form developed to collect data was used as a data collection tool and data analysis was carried out with content analysis. It was determined that $64 \%$ of the teachers in the study group did not include experimental work in their courses in the distance education process, and they put forward six reasons: environment inconsistency, student-oriented, program-oriented, exam-oriented, personal and technical reasons. It was determined that $72 \%$ of the teachers were aware of the interactive experiment videos on the OGM material site, while $66 \%$ of the chemistry teachers viewed these experiment videos. While 26 of the 31 teachers who examined the experiments stated that the videos were useful, suitable for the student's level and could contribute to learning, it was concluded that five teachers thought the videos were insufficient numerically. Another conclusion reached in the study is that most of the chemistry teachers participating in the study want to receive training on how to use experimental studies in lessons during the distance education process. At the end of the study, suggestions about how chemistry teachers can add experimental studies to their lessons and for the training of prospective chemistry teachers are given. Thus, it is foreseen that the results of the study can be a guide for teachers working in schools that do not have laboratory facilities, as well as how experimental studies can be added to the lessons in case of possible distance education planning.

Keywords: Covid-19 pandemic, chemistry teachers, experimental study.

\section{Giriş}

Covid-19 sürecinde yaşananlar insanların tümünü ve her düzeyde iş ortamını etkilediği gibi öğretim sürecinin yürütülmesini de oldukça fazla etkilemiştir (Bozkurt, 2020; Çakın ve Akyavuz, 2020; Zan, 2021). Virüsün yayılım hızını azaltabilmek amacıyla hızlı bir şekilde ve çok da fazla hazırlıklı olmadan uzaktan eğitime geçiş yapan bütün öğretmenler, "ne yapacağım? ve "derslerimi nasıl yürüteceğim?" gibi iki önemli soruyla karşı karşıya kalmıştır. Teorik ders anlatımları için kısa sürede çözümler üretilmiş ve EBA gibi daha önceden hazır olan portal ve burada yer alan materyal ve ders kayıtları ile öğretmenler kendilerine bir çıkış yolu bulmaya çalışmışlardır (Zan, 2021). Diğer taraftan teorik dersler kadar çözüm bulunması kolay olmayan ve aynı zamanda daha fazla emek, zaman ve birikim gerektiren önemli bir 
durum, kimya gibi uygulama alanına sahip derslere deneysel çalışmaların nasıl dâhil edilebileceğidir.

Deneysel çalışmalar, gerek laboratuvarda bizzat öğrencinin gerçekleştireceği deneyler gerekse öğretmenin gösteri deneyi şeklinde yapacağı deneyler ile bilgisayar ortamında öğrencilerin sanal laboratuvar ortamında veya etkileşimli/etkileşimsiz deney videolarının izlettirilmesi ile gerçekleştirilen tüm çalışmaları kapsamaktadır. Deneysel çalışmalar hangi şekilde yürütülürse yürütülsün öğretmenlerin doğru yönlendirmeleri ile öğrencinin bilimsel süreç becerileri başta olmak üzere, eleştirel düşünme becerisi, problem çözme becerisi ve anlamlandırma becerisi gibi üst düzey düşünme becerilerini geliştirilmesine önemli katkı sağlayabilir (Nakiboğlu, 2021). Bunun yanında bilimsel çalışma yolunu öğrencilere tanıtmak ve öğrencileri bilime teşvik etmek ve derse olan ilgi ve tutumlarını arttırarak duyuşsal alana yönelik gelişimlerine de katkı sağlayabilir (Morgil, Seyhan ve Seçken, 2009).. Öğrencilerin bilişsel, duyuşsal ve devinişsel anlamda gelişmelerine bu derece katkısı olan deneysel çalışmalardan laboratuvar ortamında deney yapılmasına yönelik kimya öğretmenlerinin neler yaptıklarını araştıran çalışmalar incelendiğinde, yüz yüze eğitimdeyken bile farklı nedenlerle kimya öğretmenlerinin derslerinde laboratuvar çalışmalarına yer vermediği veya derslerinde laboratuvar kullanımına çok olumlu yaklaşmadıkları görülür (Akaygün vd., 2016; Akkuş \& Kadayıfçı, 2007; Demir vd., 2017, Erbil, Demir \& Erbil, 2021 Feyzioğlu, 2014; Nakiboğlu \& Sarıkaya, 1999; Nakiboğlu \& Sarkkaya, 2000; Özden, 2007; Özmen, 2004). Yüz yüze derslerin yürütüldüğ̈̈ ortamda öğretmenlerin laboratuvar kullanmama veya deney yaptırmama ile ilgili ileri sürdükleri nedenler incelendiğinde, bunların zaman darlığı, programı yetiştirememe endişesi, madde malzeme eksikliği ve deney yapacak ortamın bulunmaması gibi ana başlıklar altında toplandığı görülmektedir; (Nakiboğlu \& Sarıkaya, 1999; Nakiboğlu \& Sarıkaya, 2000; Özden, 2007; Özmen, 2004). Bu açıdan bakıldığında ilk iki neden uzaktan eğitimde de geçerli görünse de öğretmenlerce ileri sürülen üçüncü ve dördüncü nedenler uzaktan eğitimin süreci ile kismen de olsa ortadan kaldırdığı söylenebilir. Çünkü uzaktan eğitimde gerçek laboratuvarların yerini sanal laboratuvarlar ve madde ve malzemenin yerini deney videoları almış durumda olup ulaşılması nispeten daha kolaydır. Diğer taraftan bu tür uygulamaları kullanmak öğretmenlerin teknolojik yeterlilikleri yani teknolojik pedagojik alan bilgileri ile ilgilidir (Srisawasdi, 2014). Ayrıca derslere deneysel çalışmaları eklemek için farklı hazırlıklar yapılması ve dersin bu yeni duruma göre planlanması da gerekmektedir (Nakiboğlu, 2021). Tüm bunlara uzaktan eğitimin verdiği birtakım sıkıntılarda eklendiğinde, uzaktan eğitim sürecinde de kimya derslerinde laboratuvar kullanımı ile ilgili durumun ortaya konulması ve buna bağlı olarak kimya öğretmenlerine çözüm önerilerinin sunulması gerekir.

Alan yazında Covid-19 sürecinde Türkiye'de farklı branşlarda görev yapan öğretmenlerin ve öğretmen adaylarının uzaktan eğitim sürecinde derslerin yürütülmesine yönelik düşünce ve algıları ile kullandıkları yöntemlerin incelendiği bazı çalışmalar bulunmakla birlikte (Aydın ve Erol, 2021; Bakioğlu ve Çevik, 2020; 
Bayburtlu, 2020; Karakuş, Ucuzsatar, Karacaoğlu, Esendemir ve Bayraktar, 2020; Metin, Gürbey ve Çevik 2021; Orhan ve Beyhan, 2020), kimya öğretmenleri ile yapılan çalışma sayısı nispeten sınırlıdır (Zan, 2021). Bakioğlu ve Çevik (2020), Covid-19 sürecinde Fen Bilimleri öğretmenleri ile yürüttükleri çalışmada, uzaktan eğitim sürecinde öğretmenlerin hem derste kullandıkları öğretim yöntem ve tekniklerin hem de kullandıkları materyallerinin değiştiği, uzaktan eğitim ile öğretim programını ve laboratuvar/ atölye etkinliklerini tamamlayamama gibi kaygılara da sahip oldukları görülmüştür. Ancak, bu olumsuzluklar yanında uzaktan eğitim süreci, öğretmenlerin eğitim teknolojileri kullanımlarını ve bu yöndeki mesleki gelişimlerini çoğunlukla olumlu yönde etkilediği belirlenmiştir.

Bayburtlu (2020), Türkçe öğretmenlerinin okulların kapalı olduğu salgın döneminde, öğrencilerin Türkçe eğitiminden kopmamaları için çeşitli video ders programları, sosyal mesajlaşma uygulamaları kullanarak öğrenciler ve velileri ile iletişim halinde olduklarını belirlemiştir. Çalışmada, öğretmenlerin bir kısmının öğrencilerinden bazılarının bilgisayar veya tablet sahibi olmamaları nedeniyle canlı derslere katılamadıklarını ifade ettikleri sonucuna ulaşılmıştır. Karakuş vd. (2020) de çalışmalarında Türkçe öğretmen adaylarının uzaktan eğitime yönelik görüşlerini araştırmışlardır. Çalışma sonunda öğretmen adaylarının, uzaktan eğitimde karşılaştıkları en büyük sorunun bağlantı sorunu olduğu, uzak eğitimin sosyalleşmeye katkı düzeyinin orta düzeyde olduğunu ve motivasyona olan katkı düzeyinin ise düşük olduğunu düşündükleri belirlenmiştir. Ayrıca çalışmada, öğretmen adaylarının uzaktan eğitime devam edilmesine olumlu bakmadıkları ve bu süreci genel olarak olumsuz değerlendirdikleri sonucuna ulaşılmıştır.

Orhan ve Beyhan (2020) farklı alanlardan öğretmenlerin Covid-19 pandemisi sürecinde uzaktan eğitime ilişkin algılarını ve öğretme deneyimlerini inceledikleri çalışma sonunda, öğretmenlerin çoğunun uzaktan eğitimi yeni bir öğretim modelinden ziyade teknoloji odaklı bir süreç olarak algıladıklarını belirlemişlerdir. Ayrıca öğretmenlerin uzaktan eğitimde de yüz yüze yaptıkları öğretime benzer şekilde geleneksel öğretim teknikleri kullanmaya devam ettikleri sonucuna ulaşmışlardır. Erbil ve diğ. (2021), uzaktan eğitim sürecini sınıf öğretmenleri görüşleri 1şığında değerlendirilmesini amaçlayan bir çalışma gerçekleştirmişlerdir. Çalışma sonucunda elde edilen bulguları, fiziksel altyapı, veli, öğretmen, öğrenci, uygulama boyutu (ders), kullanılan öğretim yöntem ve teknikleri ve eğitim bilişim ağı olmak üzere yedi tema altında toplamışlardır. Öğretmenlerin fiziksel altyapı temasında en çok teknolojik araç gereç eksikliği ile ilgili sorunları dile getirirken, öğretmenlerin önemli bir kısmının uzaktan eğitim konusunda yeterli eğitim almadıkları belirlenmiştir. Öğretmenlerin uzaktan eğitimde izledikleri öğretim yöntem ve tekniklerinin çoğunlukla geleneksel anlayışa dayalı olduğu belirlenirken, öğretmenlerin yüz yüze eğitim sürecinde olduğu gibi, uzaktan eğitim sürecinde de anlatım, soru-cevap, gösteri, örnek verme gibi geleneksel anlayışta yer alan yöntemteknikleri kullandıkları sonucuna ulaşılmıştır. 
Metin, Gürbey ve Çevik (2021) farklı branşlardaki öğretmenlerin uzaktan eğitime ilişkin görüşlerini inceledikleri çalışmada, öğretmenlerin genel olarak uzaktan eğitime yönelik olumsuz görüşlere sahip olduklarını belirlemişlerdir. Öğretmenlerin özellikle sınıf kontrolünü sağlama, öğrenciler ile etkili iletişime geçebilme, öğrencilerin motivasyonların arttırma ve derse katılımlarını sağlama ile ilgili sorunları olduğu sonucuna ulaşılmıştır. Ayrıca uzaktan eğitimin öğretmenlerin iş yükünü arttırdığ 1 ve öğretmenlerin uzaktan eğitimde kullanılan teknolojik aletleri ve programları kullanabilme becerisi açısından_çok yeterli olmadıkları belirlenmiştir.

Kimya öğretmenleri ile Türkiye'de yürütülen çalışma Zan (2021) tarafından gerçekleştirilmiştir. Bu çalışmada Zan (2021) kimya ve kimya teknolojileri öğretmenlerinin uzaktan eğitim sürecinde yaşadıkları sorunları, öğretmen- öğrenciler, teknoloji ve öğretim programı bağlamında değerlendirmiştir. Ayrıca uzaktan eğitim sürecinin öğretmenin gelişimine etkisi ve öğretmenlerin MEB'den beklentileri de bu çalışmada araştırılmıştır. Çalışma sonunda öğretmenlerin büyük bir kısmının düzenli olarak her hafta ders saatlerinde öğrencilere ders anlattıkları belirlenirken, az bir kısmının ise ya düzenli ders işleyemediği ya da konu anlatımını farklı sebeplerden gerçekleştirememesi nedeniyle öğrencilere ödev verdiği belirlenmiştir. Derslerini işlerken öğretmenlerin önemli bir kısmı EBA canlı yayın uygulamasını veya EBA ve Zoom uygulamasını birlikte kullandığı, bir kısmının sadece Zoom uygulamasını kullandığı sonucuna ulaşılmıştır. Bunların yanında Whatsapp, sosyal medya uygulamalarını ve farklı uygulamalara yönelen öğretmenler olduğu da görülmüştür.

Zan (2021), ayrıca kimya öğretmenlerinin ders anlatım sırasında kullandıkları yöntemleri incelediğinde, çalışmaya katılan öğretmenlerin yarısından fazlasının sorucevap ve düz anlatım yöntemini kullanırken, bir kısmının yaşam temelli öğrenme, tartışma ve proje tabanlı öğrenme yöntemlerini kullandıklarını belirlemiştir. Kimya öğretmenlerinden, uzaktan eğitim sürecini yoğunluk açısından değerlendirmeleri istendiğinde, öğretmenlerinin neredeyse yarısının aşırı yoğun bir dönem geçirdiklerini fazla mesai yaptıklarını ifade ettikleri görülmüştür. Bunların yanında öğretmenlerin bu dönemle ilgili kazanımları incelendiğinde diğer öğretmenlerle yürütülen çalışmalarda ulaşılan sonuçlara benzer şekilde en fazla teknolojik anlamda gelişme yaşadıklarını ifade ettikleri sonucuna ulaşılmıştır.

Kimya öğretmenleri ve diğer öğretmenlerle yürütülen tüm çalışmalar için ortak olan bir noktanın geleneksel öğretim yöntem ve tekniklerinin uzaktan öğretim sürecinde de kullanımının ön planda olduğudur. Diğer taraftan 2018 Yılı Kimya Dersi Öğretim Programı (Milli Eğitim Bakanlığ1 [MEB], 2018a) ve 2018 Y1lı Fen Lisesi Kimya Dersi Öğretim Programı (MEB, 2018b) incelendiğinde, programların etkinlik ve deneysel çalışmalara son derece önem verdiği görülür (Demir, 2021; Nakiboğlu, 2021). Bu nedenle yüz yüze yürütülen eğitimde olduğu kadar uzaktan eğitimde yürütülen kimya derslerinde de deneysel çalışmaların uygun şekilde ders içinde yer alması program kazanımları ile programın amaçlarına ulaşılması açısından son derece önemlidir. Bu düşünceden yola çıkarak çalışmada, Covid-19 sürecinde, uzaktan yürütülen kimya derslerinde, öğretmenlerin derslerinde deneysel çalışmalara yer 
verip vermedikleri, yer vermemeleri durumunda bunların nedenlerinin betimlenmesi amaçlanmıştır. Bu amaç doğrultusunda çalışmanın alt problemleri aşağıdaki şekilde verilebilir.

1. Kimya öğretmenleri uzaktan eğitim sürecinde derslerinde deneysel çalışmalara yer verme durumları nasıldır?

2. Kimya öğretmenlerinin uzaktan eğitim sürecinde derslerinde deneysel çalışmalara neden yer vermemektedirler?

3. Kimya öğretmenleri OGM Materyal sitesinden yer alan etkileşimli deney videolarından haberdar mıdır ve deney videoları hakkındaki düşünceleri nasıldır?

4. Kimya öğretmenlerinin uzaktan eğitim sürecinde derslerde deneysel uygulamalara yer verme konusunda eğitim almaya yönelik düşünceleri nelerdir?

5. Kimya öğretmenlerinin uzaktan eğitim sürecinde deneysel uygulamalara yer verme ile ilgili genel önerileri var mıdır?

\section{Yöntem}

Bu çalışmada nitel araştırma yöntemi kullanılmıştır. Bu yöntemin bir deseni olan durum çalışması tercih edilmiştir. McMillan (2000) tarafından durum çalışması bir ya da daha fazla olayın, ortamın, programın, sosyal grubun ya da birbirine bağlı diğer sistemlerin derinlemesine incelendiği yöntem olarak tanımlamaktadır (akt. Büyüköztürk, Kılıç, Çakmak, Akgün, Karadeniz ve Demirel, 2009). Aksoy (2016), durum çalışmasının en önemli özelliğinin, çalışmada yer alan durumun, kişinin ya da topluluğun kendine özgü özellikleri nedeniyle seçilmesi ve kendi bağlamı içinde ele alınması olduğunu belirtmiştir.

Bogdan ve Biklen (1998) durum çalışmalarında incelenen birimin bir kişi veya topluluk olmasının yanında topluluğun özel bir süreçteki durumu şeklinde de olabileceğini ifade etmişlerdir (akt. Aksoy, 2016). Bu nedenle çalışmada kimya öğretmenlerinin Covid-19 salgin sürecinde zorunlu olarak uzaktan eğitim şeklinde yürütülen ortaöğretim kimya derslerinde, deneysel çalışmalara yer verme veya vermeme durumları ile yer verilmemesine ilişkin nedenler kendi bağlamı içinde incelenmiştir. Çalışma, Aksoy (2016) tarafından belirtilen "topluluğun kendine özgü özellikleri nedeniyle" ve Bogdan ve Biklen (1998) tarafından ifade edilen "topluluğun özel bir süreçteki durumu" nedeniyle, durum çalışması olarak ele alınmıştır.

\section{Çalışma Grubu}

Araştırmanın çalışma grubunu 2020-2021 eğitim-öğretim yılı güz ve bahar dönemlerinde uzaktan eğitim sürecinde Türkiye' nin farklı illerinde görev yapan 36 kadın ve 11 erkek olmak üzere toplam 47 kimya öğretmeni oluşturmaktadır. Çalışmada kolay ulaşılabilir örnekleme yöntemi kullanılarak maksimum çeşitlilik 
sağlanmasına da dikkat edilerek veri toplanmış olup kimya öğretmenlerine ait demografik veriler Grafik 1'de sunulmuştur.

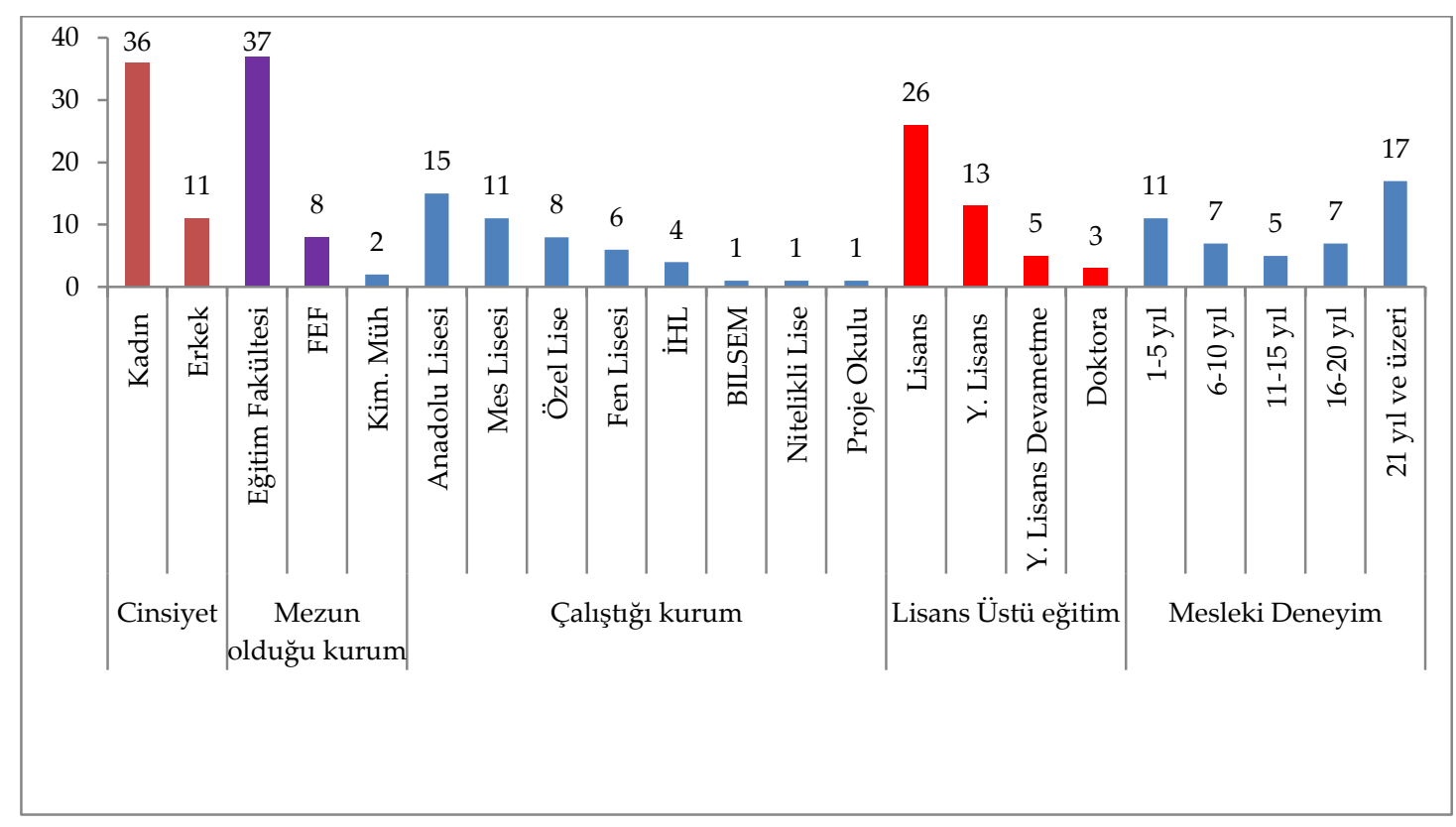

Grafik 1. Çalışma grubunda yer alan kimya öğretmenlerinin demografik özellikleri

Grafik 1 incelendiğinde, çalışmaya katılan kimya öğretmenlerinin $37^{\prime}$ sinin eğitim fakültelerinin kimya öğretmenliği programlarından, sekizinin fen edebiyat fakültelerinin kimya bölümlerinden ve ikisinin de kimya mühendisliği bölümünden mezun olduğu görülmektedir. Kimya öğretmenlerinin görev yaptıkları okul türleri incelendiğinde, 15 öğretmenin Anadolu liselerinde, 11 öğretmenin meslek liselerinde, sekiz öğretmenin özel liselerde, altı öğretmenin fen liselerinde, dört öğretmenin imamhatip liselerinde, bir öğretmenin proje okulunda, bir öğretmenin nitelikli lisede ve bir öğretmenin de BİLSEM'de görev yaptı̆̆ belirlenmiştir. Öğretmenlerin eğitim dereceleri incelendiğinde, 26 öğretmenin lisans derecesine sahip olduğu ama bunlardan beş öğretmenin yüksek lisans eğitimlerine devam ettikleri, 13 kimya öğretmeninin yüksek lisans ve üç kimya öğretmeninin de doktora derecesine sahip olduğu görülür. Kimya öğretmenlerinden 11'inin mesleki deneyimi 1-5 yıl arasında, diğer yedi kimya öğretmeninin mesleki deneyiminin 6- 10 yıl arasında, beş kimya öğretmenin mesleki deneyimi 11-15 yıl arasında, yedi kimya öğretmeninin mesleki deneyimi 16-20 yıl arasında ve 17 kimya öğretmenin mesleki deneyimi 21 yıl ve üzerindedir.

\section{Veri Toplama}

Çalışmada veri toplamak üzere geliştirilen ölçme aracının geliştirilmesi ve içeriği ile ilgili ayrıntılara aşağıda verilmiştir. 


\section{Veri Toplama Aracı}

Bu makalede sunulan veriler, üniversite düzeyinde ve ortaöğretim düzeyinde deneysel çalışmaları inceleyen oldukça kapsamlı bir araştırmanın bir kısmını içermektedir. Ortaöğretim kısmı için veri toplamak üzere yazar tarafından iki adet "yazılı görüş formu" geliştirilmiş olup bu çalışmada birinci yazılı görüş formu verilerine yer verilmiştir. Yazılı görüş formlarının geliştirilmesi sürecinde yazar, üniversite düzeyinde öğretim üyelerinin laboratuvar kullanımına yönelik görüşlerini incelemek amacıyla geliştirdiği formdan yararlanarak ilk olarak bir adet "çevrimiçi lavoratuvar öğretimi” isimli bir Google formu hazırlamıştır. Üç bölümden oluşan taslak yazılı görüş formunun ilk bölümünde çalışma içeriği ile ilgili açılama ve gönüllü katılım onayı yer almakta olup ikinci bölüm kişisel bilgilere yönelik üç adet soru içermektedir. Üçüncü bölüm 9 adet açık uçlu ve üç adet açıklama kısmı içeren soru ile bir adet açıklama kısmı içermeyen çoktan seçmeli soru olmak üzere toplam 13 soru içermektedir. Hazırlanan form bir alan uzmanından görüş alındıktan sonra iki kimya öğretmenine uygulanmıştır. Yazılı görüş formunun analizi sonucunda öğretmenlerin "laboratuvar" kelimesini daha çok yüz yüze laboratuvar yapılması şeklinde algıladığının görülmesi nedeniyle amaca daha uygun ve daha kapsamlı olan "deneysel çalışmalar" ifadesi ile değiştirilmesine karar verilmiştir. Ayrıca yüksek lisans yapmakta olan ve deneysel çalışmaları derslerinde sık kullanan bir fen bilimleri öğretmeni ile yüksek lisans tamamlamış ve tez aşamasında görüş ölçeği geliştirmiş ve bu konuya hâkim olan deneyimli bir kimya öğretmeninden yazılı görüş formunun sorularının anlaşılabilirliği ve amaca hizmeti konusunda yazılı görüş formunun görünüş geçerliliğini sağlamak amacıyla görüş alınmıştır. Bu görüşler ve uygulanan taslak yazılı görüş form cevaplarının analizinin sonuçlarına bağlı olarak yazılı görüş formu son hale getirilmiştir. Bu yazılı görüş formunun 10 kimya öğretmenine uygulanması sonucunda "kimya öğretmenlerinin uzaktan eğitim sürecinde deneysel çalışmalara yönelik deneyimleri” başlıklı bir yazılı görüş formu oluşturulmuştur. Ancak geliştirilen yazılı görüş formunun analizi, kimya öğretmenlerin uzaktan eğitim sürecinde deneysel çalışmaları derslerinde nasıl kullandıklarına yönelik deneyimlerini derinlemesine incelemeden önce, kimya öğretmenlerinin deneysel çalışmaları derslerinde yer verme durumlarının genel değerlendirilmesinin yapılmasının daha uygun olacağı düşüncesini ortaya çıkarmıştır. Bu düşünceden yola çıkarak "uzaktan eğitim sürecinde kimya öğretmenlerinin deneysel çalışmalara yer vermeye yönelik durum değerlendirmesi" amaçlı ikinci bir yazılı görüş formu hazırlanmıştır. İkinci form ile ilgili pilot uygulama yapılıp görüş alınması ile yazılı görüş formu son hale getirilmiştir. Her iki yazılı görüş formunun içerdiğinin farklı olması ve açık uçlu soru sayısının çokluğu ve her ikisinin farklı amaçlara hizmet etmesi nedeniyle, formlar ayrı ayrı uygulanmış ve analiz edilmiştir. Bu makalede de çalışmanın ilk aşaması olan kimya öğretmenlerinin deneysel çalışmalara yer vermeye yönelik durum değerlendirilmesi için hazırlanan yazılı görüş formunun analizine ait bulgulara yer verilecektir. Bu şekilde geliştirilen formun ilk bölümü çalışmanın içeriğinin tanıtımı ve çalışma onayının istendiği; ikinci bölümü kişisel bilgilere yönelik 
soruların yer aldığı ve üçüncü bölümü, deneysel çalışmaya yer verme durumu ile ilgili yedi adet görüş sorusu içermektedir. Bu soruların dört tanesi evet/hayır şeklinde cevap verilecek tarzda sorular olup sorulardan bir tanesinde evet ve hayır cevabını verenlerden ayrı ayrı açıklama yapmaları istenmiştir. Yazılı görüş formunun diğer üç sorusu açık uçlu soru şeklindedir.

Çalışmanın yürütülmesinden önce Balıkesir Üniversitesi Fen ve Mühendislik Etik Kurulundan etik kural izni alınmıştır. Veri toplama aşamasında öğretmenlere çalışma hakkında gerekli açıklama yapılarak çalışmaya katılım onayı alınmış, gönüllü olanlar çalışmaya dâhil edilmiş ve isimleri ve görev yaptıkları il/ilçe isimleri istenmemiştir.

\section{Verilerin Analizi}

Çalışmada açı uçlu sorulardan toplanan verilerin analizinde içerik analiz kullanılmış ve elde edilen nitel veriler sayısallaştırılarak nicel olarak sunulmuştur. Yıldırım ve Şimşek (2011) tarafından belirtildiği gibi nitel verilerin sayılara indirgenmesi mümkündür (s., 242). Nitel verinin belirli ölçüde sayıya dökülmesi verinin analizi sonucunda ortaya çıkan tema veya kategoriler arasında karşılaştırma yapılmasına olanak verebilir (s. 243). Görüş formunun sadece evet veya hayır ya da sadece şık seçimi yapılarak cevaplanan sorularına verilen cevaplar frekans olarak sunulurken, açık uçlu soruların sunumu için temalar oluşturulmuş ve veri sunumunda ilgili temalara ait örnek ifadelere de yer verilmiştir.

Açık uçlu soruların içerik analizi yapılırken öğretmenlerin yazılı olarak ifade ettiği söylemlerinde benzer ifadelerin sinıflandırılması ile önceden belirgin olmayan kategorilerin kodlaması ile temaların oluşturulma yolu izlenmiştir (Berg, 1998). Açık uçlu sorulara ait bulgular sunulurken, ilgili yerlerde öğretmen ifadelerinden yapılan alıntılar ile veriler desteklenmiştir. Veri analizinin kodlayıcı güvenirliğinin sağlanması amacıyla veriler araştırmacı tarafından farklı zamanlarda iki kez analiz edilerek karşılaştırılmış (Miles ve Huberman (1994) tarafından oluşturulan güvenirlik hesaplamasına göre güvenirlik katsayısı 0,95 olarak belirlenmiş) ve uyumsuz durumlar tekrar incelenerek analiz sonuçları son hale getirilmiştir. Ayrıca makale yazım sürecinde tüm veriler üçüncü kez analiz edilerek karşılaştırılmıştır. Üçüncü analiz sırasında herhangi bir farklı duruma rastlanmamıştır.

\section{Bulgular}

Çalışmanın bulguları her bir araştırma problemine yanıt oluşturacak şekilde aşağıda sunulmuştur.

\section{Birinci Araştırma Problemine Yönelik Bulgular}

İlk araştırma probleminde, 2020- 2021 eğitim öğretim y1lında uzaktan öğretim sürecinde kimya dersi veren öğretmenler derslerinde deneysel çalışmalara yer verme durumları araştırılmıştır. Bu amaçla sorulan "uzaktan eğitim sürecinde derslerinizde 
deneysel çalışmalara yer verdiniz mi?" sorusuna verilen cevapların analizine ait bulgular Grafik 2' de verilmiştir.

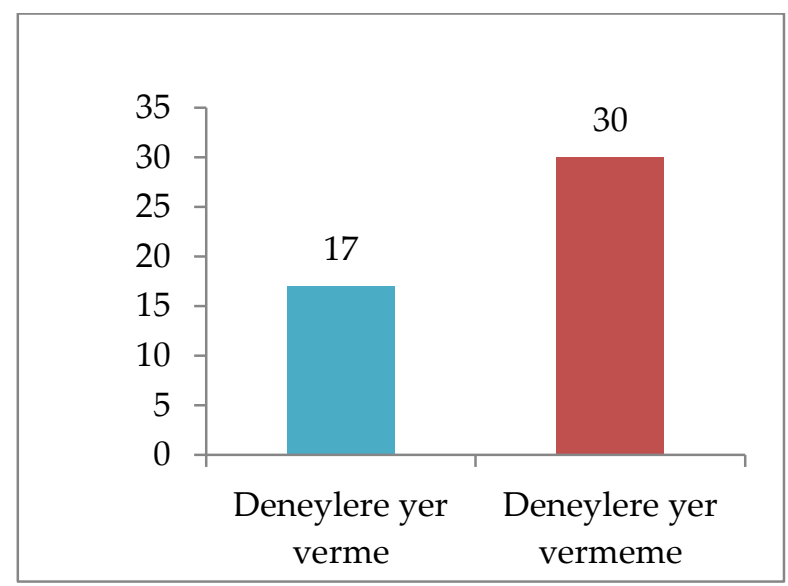

Grafik 2. Uzaktan öğretim sürecinde kimya dersi veren öğretmenlerin derslerinde deneysel çalışmalara yer verme durumu

Grafik 2 incelendiğinde çalışmaya katılan öğretmenlerden 17'sinin (\%36) uzaktan eğitim sürecinde derslerinde deneysel çalışmalara yer verdiklerini ifade ettikleri görülürken, 30 (\%64) kimya öğretmenin ise uzaktan eğitim sürecinde derslerinde deneysel çalışmalara yer vermediğini ifade ettiği görülür.

\section{İkinci Araştırma Problemine Yönelik Bulgular}

İkinci araştırma probleminde uzaktan eğitim sürecinde deneysel çalışmalara derslerinde yer vermediği ifade eden kimya öğretmenlerinin derslerinde deneysel çalışmalara neden yer vermedikleri araştırılmıştır. Bu amaçla yazılı görüş formunun ikinci sorusunda öğretmenlerden uzaktan eğitim sürecinde derslerinde deneysel çalışmalara yer vermemeleri durumunda, bunun nedenini açılamaları istenmiştir. Bu soruya verilen cevapların analizine ait bulgulara Tablo 1'de gösterilmiştir.

Tablo 1. Kimya öğretmenlerinin uzaktan öğretim sürecinde deneylere yer vermeme nedenleri $(N=30$

\begin{tabular}{|c|c|c|c|c|}
\hline Kod & İfade örnekleri & & f & $\%$ \\
\hline Ortamin & İmkânlarımız kısıtlı & 4 & 9 & 30 \\
\hline \multirow{2}{*}{ Uygunsuzluğu } & Ev ortamında olmamiz & 2 & & \\
\hline & Uygun ortam olmaması & 4 & & \\
\hline \multirow{3}{*}{$\begin{array}{l}\text { Öğrenci odaklı } \\
\text { nedenler }\end{array}$} & Öğrenci katılım düşük & 6 & 8 & 27 \\
\hline & Öğrencilerin akademik başarısı düşük & 1 & & \\
\hline & Öğrencilerin kontrolünün zor olması & 1 & & \\
\hline \multirow{3}{*}{$\begin{array}{l}\text { Program odaklı } \\
\text { nedenler }\end{array}$} & Ders saati kısitlı & 4 & 8 & 27 \\
\hline & Müfredat fazla olması & 3 & & \\
\hline & Zaman sıkıntısı & 1 & & \\
\hline \multirow{2}{*}{$\begin{array}{l}\text { Sinav odaklı } \\
\text { nedenler }\end{array}$} & Soru çözümü yapmak & 3 & 6 & 20 \\
\hline & Sinav gruplarında derse girmem nedeniyle & 2 & & \\
\hline
\end{tabular}




\begin{tabular}{lllll}
\hline \multirow{3}{*}{ Kişisel nedenler } & Sinav sistemine göre yetiştirme & 1 & & \\
& Online derslerin çok yeni olması & 1 & 5 & 17 \\
& Ani gelişen duruma karşı hazırlıklı olmamak & 1 & & \\
& Zorluk & \multicolumn{1}{c}{1} & \\
& Nasıl yürütüleceğini bilmeme & \multicolumn{2}{c}{1} & \\
& Deneyler yüz yüze eğitimde etkilidir. & \multicolumn{2}{c}{7} \\
\multirow{2}{*}{ Teknik nedenler } & Video açınca EBA dersten atıyor & 1 & 2 & 7 \\
& Çevrim içi uygulama programlarının yetersizliği & 1 & & \\
\hline
\end{tabular}

Tablo 1 incelendiğinde, kimya öğretmenlerinin uzaktan eğitim sürecinde deneysel çalışmaları derslerinde kullanmama nedenlerinin altı kod altında toplandığı görülür. İlk kod, öğretmenlerin 9'unun ifadelerinin altında toplandığ 1 "ortam uygunsuzluğu" kodudur. $\mathrm{Bu}$ kod incelendiğinde, öğretmenlerin ev ortaminda olmaları ve imkânlarının sınırlı olması, onları deneysel çalışmalara derslerinde yer vermemeye götürdüğünü ifade ettikleri görülür. Bu kod ile ilgili iki öğretmenin açılamalarından yapılan alıntılar aşa ğıda verilmiştir.

Deneysel çalışmalara çok yer veremiyoruz daha çok görseller videolar üzerinden öğrencilere aktarmaya çalışıyoruz çünkü ders saatlerimiz ve imkânlarımız kısıtlı (KÖ7)

Uzaktan eğitimin bu uygulamaya uygun olmayışı (KÖ36).

KÖ7 kodlu kimya öğretmeni, eğitim fakültesi kimya öğretmenliği mezunu olup halen yüksek lisans öğrenimine devam etmekte ve özel bir kurumda öğretmenlik yapmaktadır. KÖ36 kodlu kimya öğretmeni de yine kimya öğretmenliği mezunu olup mesleki ve teknik anadolu lisesinde görev yapan doktora eğitimini tamamlamış bir kimya öğretmenidir.

İkinci kod olan "öğrenci odaklı nedenler" altında yer alan ifadeler incelendiğinde, öğretmenlerin özellikle öğrenci katılımının düşük olması nedeni üzerinde yoğunlaştı̆̆ı görülür. Bir öğretmenimiz öğrenci seviyesinin düşük olması nedeniyle, teorik derslerde bile sorun yaşadığını ve bu nedenle öğrencilerin deneysel çalışmaları anlamalarının zor olacağını düşündüğünden uygulamalar yapmadığını belirtmiştir. Bu kod altında yer alan KÖ5 kodlu, eğitim fakültesi kimya öğretmenliği mezunu olan ve özel bir kurumda öğretmenlik yapan mesleki deneyi 1-5 yıl arasındaki bir kimya öğretmenin ifadesi aşağıda örnek olarak verilmiştir.

Öğrencilerin sosyal platformda yönetimi çok zor olması nedeniyle deneysel çalışmaların să̆glıkı yürütülemedi (KÖ5).

Üçüncü kod olan "program odaklı nedenler" kodu altında yer alan ifadeler incelendiğinde, öğretmenlerin özellikle ders saatlerinin kısıtlı olması, müfredat yoğunluğu ve zaman sorunu yaşamaları derslerinde deneysel çalışmalara yer vermediklerini belirtmişlerdir. Bu kod altında yer alan KÖ16 kodlu, eğitim fakültesi kimya öğretmenliği mezunu olup mesleki ve teknik anadolu lisesinde görev yapan ve mesleki deneyimi 21 yılın üzerinde olan deneyimli bir kimya öğretmenin ifadesi örnek olarak aşağıda verilmiştir. Ayrıca bu öğretmenin ifadesinin son cümlesindeki açıklaması "teknik nedenler" kodu altında da değerlendirilmiştir. 
Ders süresinin 30 dakika, kimya ders saatinin 2 saat olması buna karşın müfredatın fazla olması. Bir de EBA'dan video açınca dersten atma yaşanabiliyor (Ö16)

Dördüncü kod olan "sınav odaklı nedenler" altında yer alan ifadeler incelendiğinde, öğretmenlerin özellikle üniversite sinavına hazırlık nedeniyle öğrencilerinin derslerde daha çok soru çözülmesini istemesi veya sistemin bunu gerektirmesi nedeniyle deneysel uygulamalar yerine soru çözümünü tercih ettiklerini ifade ettikleri belirlenmiştir. Kod ile ilgili KÖ3 ve KÖ21 kodlu kimya öğretmenlerine ait iki örnek ifade aşağıda verilmiştir. Öğretmenlerin ikisi de eğitim fakültesi kimya öğretmenliği mezunu olup yüksek lisans tamamlamışlar ve mesleki deneyimleri 6-10 yıl arasında değişmektedir. KÖ3 kodlu kimya öğretmeni meslek lisesinde görev yapıyorken KÖ21 kodlu öğretmen bir anadolu lisesinde görev yapmaktadır.

Soru çözümü şeklinde süreci devam ettiğim için deneysel çalışmalar yapmadım (KÖ3)

Online derslerin çok yeni olması ve sınav sistemine göre yetiştirilen öğrencilerin online sürelerinin oldukça sınırlı olması (KÖ21).

Tablo 1 incelendiğinde, beşinci kod olan "kişisel nedenler" altında yer alan ifadelerden ilk dört nedenin öğretmenlerin online eğitim konusunda hazırlıksız olmaları veya yeterli deneyime sahip olmamaları ile ilgiliyken son ifadenin öğretmenin deneysel çalışmaların sadece yüz yüze eğitimde yapılacağına inanması ile ilgili olduğu görülür. Bu kod ile ilgili KÖ27, KÖ30 ve KÖ47 kodlu üç kimya öğretmenine ait örnek ifadeler aşağıda verilmiştir. Öğretmenlerin hepsi eğitim fakültesi kimya öğretmenliği mezunu olup mesleki deneyimleri 21 yıl üzerindedir. KÖ27 kodlu kimya öğretmeni proje okulunda, KÖ30 bir anadolu lisesinde görev yapıyorken KÖ47 kodlu öğretmen de bir fen lisesinde görev yapmaktadır. Öğretmenlerden sadece KÖ36 yüksek lisans tamamlamış bir öğretmendir.

Öğrencilerin imkânları müsait değildi. Ayrıca şahsen ben de bu ani gelişen duruma karşı hazırlıklı değildim (KÖ27).

Uzaktan eğitimde deneylere nasıl yer vereceğimi bilmemekle birlikte zaman problemi de yaşadığım için yer veremedim (KÖ 30)

Deneyeler yüz yüze eğitimde etkilidir. Başka türlü Youtube dan da izleyebilirler (KÖ47).

Son kod olan "teknik nedenler", özellikle çevrim içi programların yetersizliği ve bağlanma ile ilgili sorunlar yaşanması gösterilmiştir. Bununla ilgili örnek bir açıklama, Ö16 kodlu kimya öğretmenine ait ifade üçüncü kod altında paylaşlırken verilmişti. $\mathrm{Bu}$ kod ile ilgili diğer bir örnek ifade eğitim fakültesi kimya öğretmenliği mezunu, mesleki deneyimleri 6-10 yıl arasında değişen ve yüksek lisans tamamlamış KÖ35 kodlu öğretmene ait olup aşağıda verilmiştir.

Uzaktan eğitimde deneysel ortam oluşturamamak, çevrim içi uygulama programlarmın yetersizliği (KÖ35). 


\section{Üçüncü Araştırma Problemine Yönelik Bulgular}

Üçüncü araştırma probleminde kimya öğretmenlerinin OGM Materyal sitesinden yer alan etkileşimli deney videolarından haberdar olup olmadıkları ve bu videoları inceleyen öğretmenlerin, videolar hakkındaki düşünceleri belirlenmeye çalışılmıştır. Bu araştırma problemine cevap bulabilmek için öğretmenlere üç adet soru yöneltilmiştir. İlk iki soruda, öğretmenlerden bu siteden haberdar olup olmadıkları ve haberdar iseler burada yer alan etkileşimli deney videolarını inceleyip incelemedikleri sorulmuştur. Bu sorulara verilen cevapların analizine ait bulgular Grafik 3'de verilmiştir.

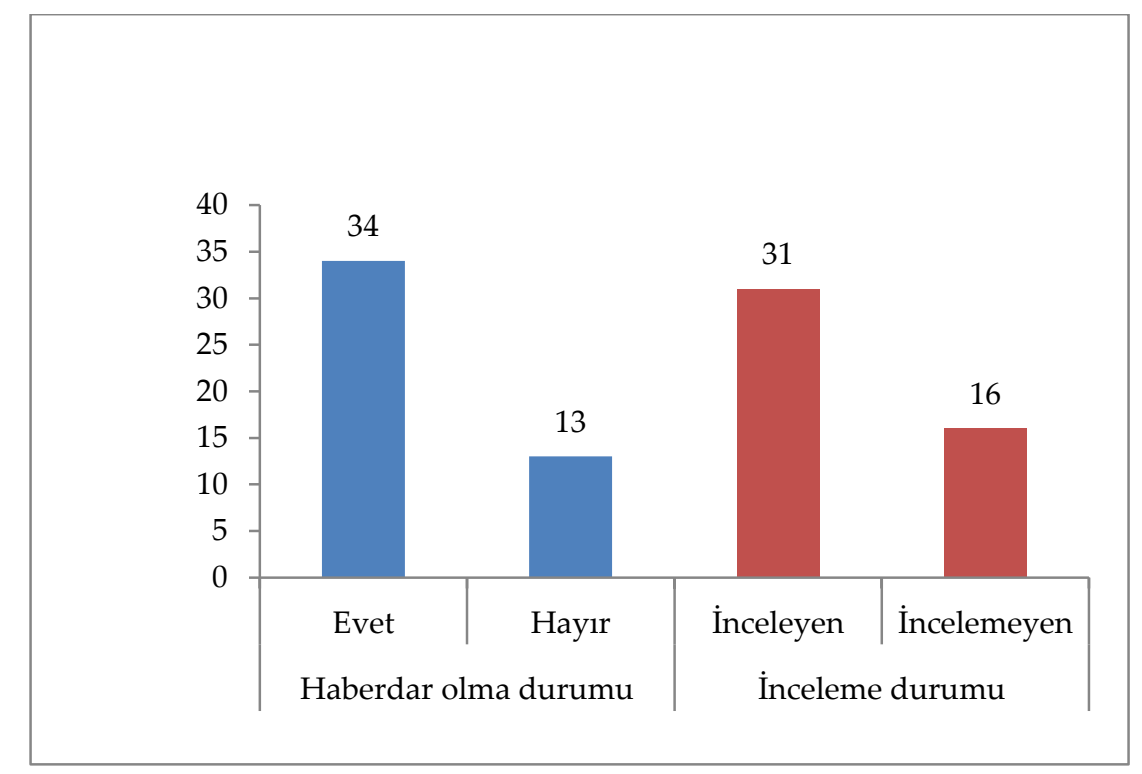

Grafik 3. Kimya dersi veren öğretmenlerin OGM Materyal sitesinden yer alan etkileşimli deney videolarndan haberdar olma ve inceleme durumlar

Grafik 3 incelendiğinde öğretmenlerden $34^{\prime}$ ü (\%72) bu siteden haberdar olduğunu belirtirken, 13'ü (\%28) haberdar olmadığını belirttiği görülür. Ayrıntılı veri analizinde haberdar olan öğretmenlerden 31'inin (\%66) bu sitede yer alan deneyleri incelediği ve haberdar olan ama incelemeyen 4 öğretmen olduğu ve haberdar olmayan öğretmenlerden birinin ise bu formu doldururken girip siteyi inceldiği belirlenmiştir. Konu ile ilgili açıklamalara aşağıda yer verilmiştir.

$\mathrm{Bu}$ alt probleme yönelik son soruda deney videolarını inceleyen öğretmenlere videolar hakkında ne düşündükleri sorulurken, incelemeyen öğretmenlere neden incelemedikleri sorulmuştur. Etkileşimli deney videolarını inceleyen 31 kimya öğretmenine ait cevapların analizine ait bulgular Tablo 2'de verilmiştir. 
Tablo 2. Kimya öğretmenlerinin OGM etkileşimli deney videoları hakkındaki düşünceleri $(N=31)$

\begin{tabular}{|c|c|c|c|c|}
\hline Kod & İfade örneği & & f & $\%$ \\
\hline \multirow[t]{10}{*}{ Deney özelliği } & Güzel /iyi & 11 & 26 & 84 \\
\hline & Faydalı/yaralı & 6 & & \\
\hline & Başarılı & 2 & & \\
\hline & Eğitici & 1 & & \\
\hline & Açıklayıcı & 1 & & \\
\hline & Etkili & 1 & & \\
\hline & Amaca uygunluk & 1 & & \\
\hline & Kimya öğretim programları hedef ve kazanımlarına uygun & 1 & & \\
\hline & Laboratuvarda uyulması gereken noktalarda dikkate alınmış & 1 & & \\
\hline & Yeterli & 1 & & \\
\hline \multirow[t]{4}{*}{ Öğrenme } & Öğrencilerin anlayabileceği düzeyde & 4 & 9 & 29 \\
\hline & Kalıcı öğrenmelerine katkı sağlayabilir. & 3 & & \\
\hline & Konuyu öğrenciye öğretebilecek düzeyde & 1 & & \\
\hline & $\begin{array}{l}\text { Öğrencinin konuyu daha iyi anlamasını/öğrenmesini } \\
\text { sağlayabilir. }\end{array}$ & 1 & & \\
\hline \multirow[t]{2}{*}{ Olumsuz görüş } & Yetersiz & 4 & 5 & 16 \\
\hline & Her konu için yeterli deney bulunmuyor & 1 & & \\
\hline \multirow[t]{2}{*}{ Öğrenci } & Deneyler genellikle öğrencilerin seviyesine uygun & 1 & 2 & 7 \\
\hline & Öğrenciler için verim sağlayabilir. & 1 & & \\
\hline
\end{tabular}

Tablo 2 incelendiğinde, kimya öğretmenlerinin OGM Materyal sitesinden yer alan etkileşimli deney videoları hakkında düşünceleri dört kod altında toplanmıştır. İlk kod olan "deney özelliği" altında yer alan ifadeler incelendiğinde bu videolara yönelik olumlu görüşlerin yer aldığı görülür. Öğretmenlerin 26’s1 (\%84) deney videolarını faydalı, etkili, açıklayıcı, programın kazanımlarına uygun, laboratuvarda uyulması gereken noktalara dikkat eden ve eğitici olarak değerlendirmektedir. İkinci kod olan "öğrenme" altında yer alan ifadeler incelendiğinde, öğretmenlerin dokuzu (\%29) bu sitede yer alan etkileşimli videoların öğrencilerin öğrenmesine katkı sağlayacağını düşündüğünü belirtmiştir. Her iki kodu da içine alan KÖ11 kodlu kimya öğretmenin açılamasından alıntı aşağıda verilmiştir.

Deney videoların inceledim. Uzaktan eğitim sürecinde derslerimde kullandım. Videoların kimya öğretim programları hedef ve kazanımlarına uygun olduğunu düşünüyorum. Özelikle deney aşamalarında durup soru yöneltip öğrencinin düşünmesine, sorgulamasına izin vermesi yönünü de ayrica çok beğendim. Çünkü uzaktan eğitim sürecinde bir öğretmen olarak ben videonun uygun gördüğüm yerlerinde durdurup öğrencilerime gerekli gördüğüm soruları yöneltebilirim (KÖ11).

$\mathrm{Bu}$ siteden haberdar olmayan öğretmenlerden bazıları, çalışmadaki formu doldururken merak edip siteyi ve buradaki deneyleri incelemiş, ayrıca bu duruma yönelik deneyimlerini de yazılı görüş formu üzerinde paylaşmışlardır. Konu ile ilgili KÖ8 kodlu kimya öğretmenin düşüncesi aşağıda yer almaktadır.

Siteyi, bu formu doldururken yeni öğrendim ve merak edip inceledim. Bence hem öğrenci hem de öğretmen için yararl bir site ve uygulama olmuş. Konuyu öğrendikten sonra ilgili deney videolarım izlemek öğrencinin konuyu daha iyi anlamasını sağlayacaktır. Laboratuvar imkânı olmayan birçok okul ve kurslar için bence ideal bir uygulama (KÖ8). 
Üçüncü kod olan "olumsuz görüş" kodu altında yer alan ifadeler daha çok sitede yer alan video sayısının yetersiz bulunması ile ilgili olduğu görülür. Bu site incelendiğinde 9. Sınıf deneyleri için bir deney, 10. Sınıf için 10 deney, 11. Sınıf için altı deney ve 12. Sınıf için beş adet deney yer almakta olup, öğretmenlerin bir kısmı deney sayısının yeterli olmadığını veya her konu için deney bulunmadığını belirtmişlerdir.

Videoların faydah olduğunu düşünüyorum ancak bu videoların artırllması gerektiğine inanıyorum (KÖ23).

Videolar iyi ama kimya için yeterli olmadığını düşünüyorum (KÖ3)

Inceledim ancak bazı deneylerin yetersiz olduğunu düşünüyorum her konu için yeterli deneyler yok (KÖ10).

Son kod olan "öğrenci" kodu altında yer alan ifadeler öğrenciye yönelik düşünceleri içermektedir. Konu ile ilgili ifadeler Tablo 2'den de görüldüğg̈ gibi deneylerin öğrenci seviyesine uygun ve öğrenci için verimli olduğu yönündeki görüşleri içermektedir. Bu siteyi incelemeyen öğretmenlerin cevapları analiz edildiğinde siteden haberdar olmayanlar "haberim olmadığ 1 için izlemedim" diye cevap verirken haberdar olmalarına rağmen incelemeyen öğretmenlerden bir tanesi "Deney yapmadığım için incelemedim (KÖ44)" diye cevap verirken bir diğeri de “Vaktim yok (KÖ46)" şeklinde cevaplamıştır.

\section{Dördüncü Araştırma Problemine Yönelik Bulgular}

Dördüncü araştırma sorusunda kimya öğretmenlerinin uzaktan eğitim sürecinde derslerde deneysel uygulamalara yer verme konusunda eğitim almaya yönelik düşünceleri araştırılmıştır. Bu amaçla sorulan bir adet çoktan seçmeli soru ve ardından bu cevaba yönelik iki açık uçlu soru yöneltilmiştir. Çoktan seçmeli soruda "uzaktan eğitim sürecinde derslerde deneysel uygulamalara yer verme konusunda eğitim almak ister misiniz?" şeklinde bir soru yöneltilip öğretmenlerden evet veya hayır şeklinde işaretlemeleri istenmiştir. Bu soruya verilen cevaplara ait bulgular Grafik 4'de sunulmuştur.

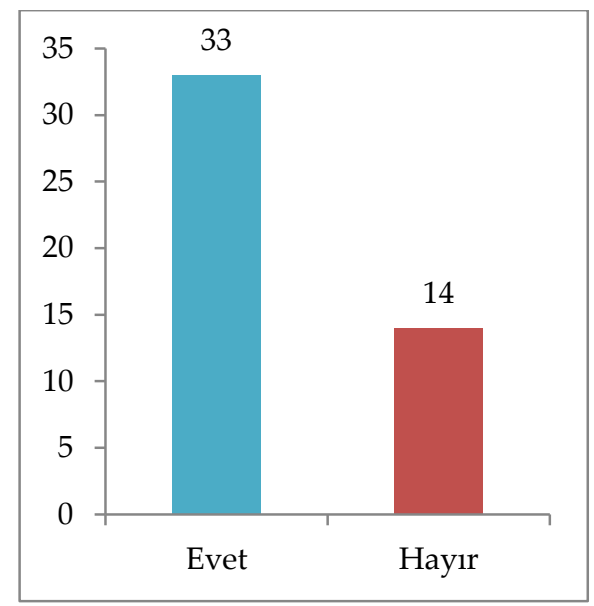

Grafik 4. Kimya öğretmenlerinin uzaktan eğitim sürecinde derslerde deneysel uygulamalara yer verme konusunda eğitim alma isteme durumları 
Grafik 4 incelendiğinde öğretmenlerin 33'ü (\%70) uzaktan eğitim sürecinde derslerde deneysel uygulamalara yer verme konusunda eğitim almak istediklerini söylerken, 14'ü (\%30) bu tür bir eğitimi almak istemediklerini belirtmişlerdir. Bu sorunun devamında yöneltilen sorulardan ilkinde, "bu soruya cevabınız evet ise, nasıl bir eğitim almak isterdiniz?" şeklinde bir soru yöneltilmiştir. Bu sorunun analizi sonucunda elde edilen bulgular Tablo 3'de verilmiştir.

Tablo 3. Kimya öğretmenlerinin uzaktan eğitim sürecinde derslerde deneysel uygulamalara yer vermeye yönelik verilecek eğitim içerik ve biçimi ile ilgili düşünceleri ( $N=33)$

\begin{tabular}{|c|c|c|c|c|c|}
\hline $\begin{array}{l}\text { Birincil } \\
\text { Kod }\end{array}$ & $\begin{array}{l}\text { İkincil Kod } \\
\end{array}$ & İfade örneği & & f & $\%$ \\
\hline \multirow[t]{15}{*}{$\begin{array}{l}\text { Eğitimin } \\
\text { içeriği }\end{array}$} & $\begin{array}{l}\text { Süreci planlama } \\
\text { eğitimi }\end{array}$ & $\begin{array}{l}\text { Derste deneysel uygulamayı nasıl kullanılacağı } \\
\text { ile ilgili eğitim }\end{array}$ & 6 & 11 & 33.3 \\
\hline & & $\begin{array}{l}\text { Deneysel çalışmaları öğrencilerin dikkatini } \\
\text { çekecek şekilde etkin bir eğitim alma }\end{array}$ & 3 & & \\
\hline & & $\begin{array}{l}\text { Deneylerden bahsederken nasıl bir süreç } \\
\text { geçirmek gerektiğini öğrenme }\end{array}$ & 1 & & \\
\hline & & Simülasyon hazırlama eğitimi & 1 & & \\
\hline & Deney & Deneyler üretme/tasarlama eğitimi & 4 & 6 & 18,2 \\
\hline & videoları/içerik & Materyal tasarlama eğitimi & 1 & & \\
\hline & üretme eğitimi & $\begin{array}{l}\text { Kendim tasarlayabileceğim deney videoları } \\
\text { oluşturan portal oluşturma eğitimi }\end{array}$ & 1 & & \\
\hline & Deneylere yönelik & Etkileşimli deneyler için eğitim almayı isteme & 2 & 6 & 18,2 \\
\hline & eğitim & Sanal Laboratuvar kullanma eğitimi & 1 & & \\
\hline & & $\begin{array}{l}\text { Deneylere nereden nasıl ulaşılabileceği ile ilgili } \\
\text { eğitim }\end{array}$ & 1 & & \\
\hline & & $\begin{array}{l}\text { Derslerde izlettirilebilecek kısa deney videoları } \\
\text { hakkında bilgi alma }\end{array}$ & 1 & & \\
\hline & & Deneyleri tanıtacak eğitim alma & 1 & & \\
\hline & Teknolojik & Bilişim dersleri almak isterim & 1 & 3 & 9,1 \\
\hline & eğitim & Teknolojik yeniliklerle ilgili & 1 & & \\
\hline & & Teknolojik eğitim & 1 & & \\
\hline Eğitimin & Online & Online olması & 6 & 6 & 18,2 \\
\hline \multirow[t]{3}{*}{ biçimi } & Yüz yüze & Yüz yüze eğitim almak isterim & 2 & 3 & 9,1 \\
\hline & & Yüzyüze ve laboratuarda yaparak & 1 & & \\
\hline & Uygulamalı & Uygulamalı seminer şeklinde & 2 & 2 & 6,1 \\
\hline
\end{tabular}

$\mathrm{Bu}$ soruda öğretmenlere verilecek eğitimin içeriğinin nasıl olmasını istedikleri sorulmasına rağmen, soruya verilen cevapların ilk analizi sonrasında kimya öğretmenlerinin bir kısmının eğitimin içeriği yanında bu eğitimin veriliş biçimi için de bazı isteklerde bulundukları belirlenmiştir. Bu nedenle Tablo 3'den de görülebileceği gibi, bu soruya ait cevaplar için öncelikle iki birincil kod oluşturulmuştur. Bunlardan ilki "eğitimin içeriği" olup bu kod altında öğretmenlerin kendilerine verilmesi istedikleri eğitimde ne gibi konulara değinilmesini yönelik isteklerinin analizine yer verilmiştir. İkinci kod olan "eğitimin biçimi” birincil kodu altında öğretmenlerin verilecek eğitimin nasıl yürütülmesi konusundaki isteklerinin analizi yer almaktadır. 
Birincil kodların analizi sırasında bunların farklı alt kodlardan oluştuğu belirlenmesi nedeniyle, daha sonra ikincil kodlara yönelik analiz gerçekleştirilmiştir. Tablo 3 incelendiğinde, birincil kodlardan ilki olan "eğitimin içeriği" kodunda yer alan cevapların dört ikincil kod altında toplandığı görülür. Bunlardan ilki olan "süreci planlama eğitimi" şeklinde etiketlenen ikincil kod altında öğretmenlerin uzaktan eğitim sürecinde deneysel uygulamaları derslerine nasıl ekleyecekleri ve bu süreci öğrencilerin ilgisini çekecek şekilde nasıl planlayabilecekleri yönünde bir eğitim alma isteğinde bulunulduğu görülür. Bu kod altında yer alan öğretmen ifadelerinden örnek üç alıntı aşağıda verilmiştir.

Uzaktan eğitim farklı bir süreç ve bunu doğru nasıl kullanabileceğim. Deneylerden bahsederken nasıl süreç geçirmem gerektiğini daha detaylı bilmek isterim (KÖ3)

Uzaktan eğitimde online olarak deneysel çalışmaları öğrencilerin dikkatini çekebilecek zevkli hale getirebilecek şekilde etkin bir eğitim almak isterim (KÖ3)

Uzaktan eğitinde deneylere nasıl yer verilebileceği konusunda yeni fikirlere ihtiyacım olabilir (KÖ32)

İkincil kodlardan "deney videoları/içerik üretme eğitimi" ile ilgili kod altında öğretmenlerin süreci nasıl planlayacaklarından çok bu içerikleri nasıl üreteceklerine yönelik bir eğitim almak istedikleri belirlenmiştir. KÖ11 kodlu kimya öğretmeni, EBA'da istediği kadar etkileşimli deney videosu olmaması nedeniyle kendisi içerik üretmek istediğini belirtmiştir. Bu öğretmenin ifadesinden bir alıntı aşağıda verilmiştir.

Uzaktan eğitim süreci için kendimin tasarlayabileceği deney videolarn oluşturabilen bir portal hazırlayabilmek üzerine bir eğitim almak isterdim (KÖ11).

Diğer bir ikincil kod olan "deneylere yönelik eğitim" altında, deney videolarına nereden ve nasıl ulaşılacağı, derslere izlettirilebilecek deney videoları hakkında bilgi edinme ve sanal laboratuvarların nasıl kullanılabileceği ile ilgili öğretmen istekleri yer almaktadır. Bu koda yönelik KÖ14 kodlu kimya öğretmenine ait ifade aşağıda verilmiştir.

Deneylere nereden nasıl ulaşılabileceği, nasıl kullanılabileceği hakkında eğitim almak isterdim (KÖ14)

Son ikincil kod olan "teknolojik destek eğitimi" altında, kimya öğretmenlerinden gerek içerik üretmek gerekse uzaktan eğitim sürecini yürütmek adına teknolojik destek eğitimlerine ihtiyaç duyduklarını belirten ifadeler etiketlenmiştir. Aşağıda verilen KÖ2 kodlu kimya öğretmenine ait ifade alıntısı, ikincil kodlardan hem içerik üretimi isteği hem de bu konuda bir teknolojik eğitim alma isteği içermesi nedeniyle her iki kod altında değerlendirilmiştir.

Öğrencilere yönelik müfredat kazanımlarına uygun deneyler üretmek isterdim. Yapım aşaması için bilişim dersleri almak, farkh web araçları ile etkileşimli içerikler oluşturmak isterdim (KÖ2)

Tablo 3'de yer alan birincil kodlardan ikincisi olan "eğitimin biçimi" altında öğretmenlerin verilecek eğitimin nasıl yürütülmesi konusundaki isteklerinin yer aldığı görülür. Bu birincil kod altında yer alan öğretmen açılamalarının "online”, yüz yüze" ve "uygulamalı" şeklinde üç ikincil kod altında toplandığı belirlenmiştir. Öğretmenlerden altısı bu tür bir eğitimin online olmasını, üç öğretmen yüz yüze 
yapılmasını ve iki öğretmenin de uygulamalı bir eğitim olmasının iyi olacağını düşündüğü görülür. Bu kodlarda yer alan kimya öğretmenlerinin ifadelerine örnek iki alıntı aşağıda verilmiştir.

Tabi ki bulunduğumuz süreç ve çalıştı̆̆ımız için eğitimler online bir platformda olsa çalışmaya katılmak isterdim (KÖ8).

Öncelikle kesinlikle yüz yüze bir eğitim almak isterim (KÖ1)

Uzaktan eğitim sürecinde derslerde deneysel uygulamalara yer verme konusunda eğitim almak istediklerini belirten kimya öğretmenlerine "bu soruya cevabınız "hayır" ise, neden bir eğitim almak istemediğinizi açıklar mısınız?" şeklinde ikinci bir soru yöneltilmiştir. Bu soruya hayır cevabı veren kimya öğretmenlerinin eğitim almayı istememelerine yönelik cevapların analizine ait bulgular da Grafik 5'te verilmiştir.

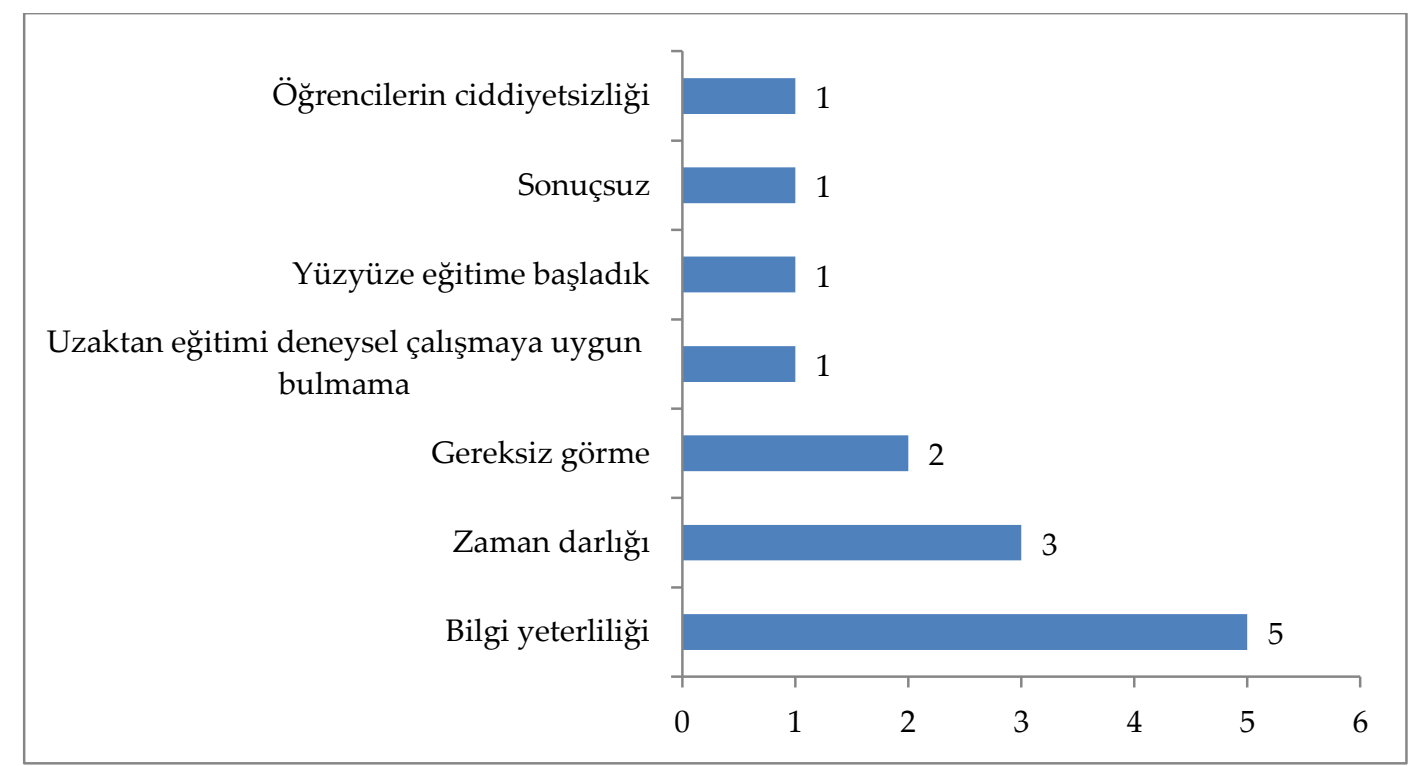

Grafik 5. Kimya öğretmenlerinin uzaktan eğitim sürecinde derslerde deneysel uygulamalara yer verme konusunda eğitim almayı istememe nedenleri

Grafik 5 incelendiğinde, kimya öğretmenlerinin bu tür bir eğitime katılmak istememe nedenleri incelendiğinde yedi grupta toplandığı görülür. Beş kimya öğretmeni tarafından ileri sürülen neden öğretmenlerin uzaktan eğitimde deneysel çalışmalara yer verme konusunda bilgilerini yeterli görmesi olduğu belirlenmiştir. Buna yönelik örnek bir ifade aşağıda verilmiştir.

Deneysel uygulamalar konusundaki bilgime eğitimim sebebiyle güveniyorum (KÖ4).

İkinci neden olarak programın çok yoğun olması, ders saatlerinin azlığ bunlara bağlı zaman yetersizliğini ileri süren kimya öğretmeni sayısı üçtür. Bu durumu KÖ9 kodlu öğretmen aşağıdaki gibi ifade etmiştir.

Almak istemem. Zaman yetersiz (KÖ9) 
KÖ25 kodlu kimya öğretmeni, öğrencilerin ders anlatımı sırasında deneysel çalışma yerine soru çözülmesini istemesi nedeniyle bu tür bir eğitime ihtiyaç duymadığını belirtmiş olup ifadesinden yapılan alıntı aşağıda verilmiştir.

Öğrenciler deneyleri ciddiye almıyorlar. Zaman kaybı olarak görüyorlar. Test çözmeyi yeğliyorlar (KÖ25).

Birinci soruda deneysel çalışmaları derslerinde kullanmadığını belirten KÖ28 kodlu kimya öğretmeni, uzaktan eğitimde deneysel çalışmaları yararlı bulmaması nedeniyle bu konuda bir eğitim almak istemediğini belirtmiştir. Bu öğretmenin açıklamalarından yapılan alıntı aşağıda verilmiştir.

Uzaktan eğitimin yüz yüze eğitime göre verimsiz olduğunu düşünüyorum. Deneyleri yüz yüze öğrencilerin kendisinin yapması daha faydalı olur diye düşünüyorum (KÖ28).

KÖ45 kodlu kimya öğretmen de birinci soruda uzaktan eğitim sürecinde deneysel çalışmaları derslerinde kullanmadığını belirtmiş ve uzaktan eğitimde deneysel çalışmalara yer vermenin çok işe yaramayacağını düşündüğü için bu konuda eğitim almak istemediği ifade etmiştir. KÖ45 kodlu öğretmenin açılamasından bir alıntı aşağıda verilmiştir.

Yapılan çalısma ve verilen emeklerin sonuçsuz kaldığını düşünüyorum (KÖ45)

\section{Beşinci Araştırma Problemine Yönelik Bulgular}

Beşince araştırma probleminde kimya öğretmenlerinin uzaktan eğitim sürecinde deneysel uygulamalara yer verme ile ilgili genel önerileri olup olmadığı araştırılmıştır. $\mathrm{Bu}$ soruya kimya öğretmenlerinden sadece $17^{\prime} \operatorname{sinin}$ dönüş yaptığ1 görülmüştür. Öğretmen sayısının azlı̆̆ı nedeniyle bulguları yüzde olarak sunmak yerine öğretmen kodlarını ve her kod altında yer alan öğretmen sayısını gösterecek şekilde tablolaştırmanın daha uygun olacağı görülmüş ve bu şekilde elde edilen bulgular Tablo 4'de gösterilmiştir.

Tablo 4. Kimya öğretmenlerinin uzaktan eğitim sürecinde derslerde deneysel uygulamalara yer vermeye yönelik ek önerileri

\begin{tabular}{|c|c|c|c|}
\hline Kod & İfade örneği & $\begin{array}{c}\text { Öğretmen kod } \\
\text { no }\end{array}$ & f \\
\hline $\begin{array}{l}\text { Öğretmene } \\
\text { yönelik öneri }\end{array}$ & $\begin{array}{l}\text { Öğretmenlere daha doğru ve verimli olarak deneyleri } \\
\text { kullanmamasını sağlayacak eğitim verilmeli } \\
\text { Öğretmen motivasyonu arttırtmalı } \\
\text { Öğretmenleri deney videoları ve animasyonlar } \\
\text { konusunda bilgilendirecek bir grup kurulmalı }\end{array}$ & $\begin{array}{l}\text { KÖ3, KÖ11, } \\
\text { KÖ36, Kö41 } \\
\text { KÖ45 } \\
\text { KÖ47 }\end{array}$ & 6 \\
\hline $\begin{array}{l}\text { Teknolojiye } \\
\text { yönelik öneri }\end{array}$ & $\begin{array}{l}\text { EBA deneysel içerikleri ve etkinliklerinin güncellenmeli } \\
\text { ve zenginleştirilmeli } \\
\text { Teknik sorunlar çözülmeli ve öğrencilerin bilgisayar } \\
\text { eksiği giderilmeli } \\
\text { Etkileşimli uygulama platformlarının arttırılmalı }\end{array}$ & $\begin{array}{l}\text { KÖ17, KÖ39 } \\
\text { KÖ33, KÖ40 } \\
\text { KÖ35 }\end{array}$ & 5 \\
\hline $\begin{array}{l}\text { Laboratuvar } \\
\text { öğretimine } \\
\text { yönelik öneri }\end{array}$ & $\begin{array}{l}\text { Derslerde deney videolarına yer verilmeli } \\
\text { Buluş ve araştırmaya dayalı laboratuvar öğretimi olmalı }\end{array}$ & $\begin{array}{l}\text { KÖ24 } \\
\text { KÖ2 }\end{array}$ & 2 \\
\hline
\end{tabular}




\begin{tabular}{lllr}
\hline $\begin{array}{l}\text { Programa } \\
\text { yönelik öneri }\end{array}$ & $\begin{array}{l}\text { Akademik liseler ile meslek liselerinin öğretim } \\
\text { programlarının kazandırılacak davranışların farklı olmalı } \\
\text { Deneyler öğretim programına homojen bir şekilde } \\
\text { yayılmalı }\end{array}$ & KÖ6 & 2 \\
$\begin{array}{l}\text { Öğrencilere } \\
\text { yönelik öneri }\end{array}$ & Öğrencilerin derslere katılımının sağlanması & KÖ4, KÖ38 & 2 \\
\hline
\end{tabular}

Tablo 4 incelendiğinde, öğretmenlerin ek olarak yaptıkları önerilerin beş kod altında toplandığ1 görülür. Bunlar öğretmene, teknolojiye, laboratuvar öğretimine, programa ve öğrencilere yönelik öneriler şeklindedir. En fazla önerinin öğretmene yönelik öneriler altında yer aldığı ve bu ifadelerden 4 tanesinin öğretmenlere uzaktan eğitim gibi süreçlerde veya yüz yüze yürütülen derslerde deney videolarının nasıl planlanıp kullanılacağına yönelik eğitim verilmesi önerisine ait olduğu görülür. Konuya yönelik KÖ3 kodlu öğretmenin ifadesinden alıntı aşağıda verilmiştir. Bu kod altındaki diğer önerilere bakıldığında KÖ45 kodlu kimya öğretmeninin motivasyonunun arttırılması için bir şey yapılmasının iyi olacağını düşündüğü belirlenmiştir. KÖ47 kodlu öğretmen ise öğretmenlere yönelik kurulacak bir grubun bu konuda kendilerine katkı sağlayacağını düşündüğünü göstermiştir. Ayrıca bu öğretmen deneysel çalışmaların özellikle fen lisesi öğrencileri için doğrudan laboratuvarda yapılmasının daha iyi olacağını ama bunun yapılmadığını da dile getirmiştir. KÖ47 kodlu öğretmenin açıklamasından yapılan alıntı aşağıda gösterilmiştir.

Deneyleri kullanma uzaktan eğitim (de) kullanma konusunda bilgilendirme yapılabilir. Bu yüz yüze eğitim sürecinde lab. olmayan okullar için kullanımı kolaylaştıracaktır. Daha doğru ve verimli olarak kullanmamızı sağlayabilir (KÖ3).

Öğretmenler için bir grup kurularak bu tür deney videolar ve animasyonlardan bilgilendirilebilir. Öğrenciler daha çok dokunmak istiyorlar. bence en etkili olanı da budur. Ancak fen liseleri gibi üniversiteye yerleştirmeye odakl eğitim veren kurumlarda deneysel uygulamalar yerine soru çözmede pratiğe ă̆ırlık vermek zorunda kalıyoruz (KÖ47).

Tablo 4'den de görüldüğü gibi, en fazla yapılan ikinci öneri teknoloji ile ilgilidir. $\mathrm{Bu}$ önerilerin özellikle EBA'da yer alan deney ve etkinliklerin iyileştirilmesi ile teknik sorunların çözülmesine yönelik olduğu görülür. EBA ile ilgili bu durumu açıklayan KÖ17 ve KÖ39 kodlu iki kimya öğretmenin açılamalarından yapılan alıntılar aşağıda verilmiştir.

Meslek lisesinde olmama rağmen özellikle basit düzeyde karışım ve çözünürlük deneylerini öğrencilerimle aktifbir şekilde yapabildim. Bu tarz çalı̧̧malar öğrencilerin çok dikkatini çekiyor. Zaten pandemi öncesinde de mesela ders işlerken eba yı sürekli kullanıyordum. Eba daki öğrencilerin katıldı̆̆̆ oyun gibi deney içerikleri de çok seviliyor. Ama bu içerikler yıllar önce yüklendi ve halen aynı içerikler devamı yok. Özellikle 11. sinıf konuları ile ilgili içerikler eklenirse daha iyi olur diye düşünüyorum (KÖ17).

EBA içerikleri zenginleştirilmeli. Daha fazla deney videolar ve etkileşimli eklenmeli (KÖ39).

Üçüncü öneri ise derslerde deneysel çalışmaların yürütülmesine yönelik olup bu konuda KÖ2 kodlu öğretmen özellikle bu tür çalışmaların buluş veya araştırmaya 
dayalı öğretim şeklinde yürütülmesinin kaliteyi arttıracağını ifade etmiştir. Öğretmenin ifadesinden alıntı aşağıda verilmiştir.

Öğrenciler bu şekilde ulaşılabilir bir uygulama açtıklarında rastgele deney aşaması tarzında bir kısmın olmasın isterdim. Öğrenci konuyu bilerek deneyi yapmasın. Deneyi yapsin ve o deneyin hangi konuya ait olduğunu basınç ilişsisini mi anlatıyor viskoziteyi mi anlatıyor kendi yorumunu katarak deneyi açıklasın isterdim. Basit düzeylerde kendi deneylerini oluşturma ortamları să̆lanırsa daha kaliteli içerik ve düzeye göre içerik sağlanmış olur (KÖ2).

Diğer önerilerden programa yönelik önerilerde, programda deneylerin daha homojen dağılması ile meslek lisesi için farklı program olmasına yönelik önerilerin yer aldığı görülür. Son öneri öğrencilerle ilgili olup öğretmenlerin her şeyden önce öğrencilerin derse katılımının sağlamasının gerektiği üzerinde durdukları belirlenmiştir.

\section{Sonuç ve Tartışma}

Bu çalışmada Covid-19 salgını nedeniyle hızlı bir şekilde geçiş yapılan uzaktan eğitim sürecinde, kimya öğretmenlerinin derslerinde deneysel çalışmalara ne düzeyde ve nasıl yer verdiğinin ve yer verilmemesi durumunda bunun nedenlerinin incelenmesi gerçekleştirilmiştir. Çalışma sonunda, kimya öğretmenlerinin \% 64'ünün derslerinde deneysel çalışmalara yer vermediği belirlenirken \% 36'sının deneysel çalışmaları derslerinde farklı şekilde kullandığı sonucuna ulaşılmıştır. Kimya öğretmenlerinin deneysel çalışmalara derslerinde yer vermeme nedenlerinin incelenmesi sonucunda, bu nedenlerin ortam uygunsuzluğu, öğrenci odaklı nedenler, program odakl nedenler, sinav odakl nedenler, kişisel nedenler ve teknik nedenler olmak üzere altı başlık altında toplandığı ortaya konulmuştur. En fazla ileri sürülen "ortamın uygunsuzluğu" nedeni ile ilgili olarak, bu döneme hazırlıksız yakalanan öğretmeler derslerini ev ortamından yürütmek zorunda kalmışlardır. Bu ortam içinde aynı zamanda küçük yaşlarda veya okula devam etmesi gereken çocuk sahibi olmaları, ders yürütecek fiziki durumun uygun olmaması veya ev içindeki olmanın verdiği sıkıntı gibi durumlar, ister istemez öğretmenlerin ders öğretimleri için yapacakları hazırlıklarını etkileşmiştir. Deneysel çalışmaları derslerde uygun şekilde kullanmak ayrı bir hazırlık, araştırma ve zaman gerektirmektedir. Bu durum "program odaklı nedenler" içinde de görülmekte, öğretmenlerin özellikle ders saatlerinin kısıtlı olması, müfredat yoğunluğu ve zaman sorunu yaşamaları derslerinde deneysel çalışmalara yer vermelerini etkilediğini göstermiştir. Bütün bunlara, derslere öğrenci katılımının düşük olması ve üniversite sınavına hazırlık nedeniyle öğrencilerinin derslerde daha çok soru çözülmesini istemesi eklendiğinde öğretmenler bu tür hazırlıkları yapmak yerine geleneksel öğretimi ve soru çözümünü tercih ettikleri belirlenmiştir. Uzaktan eğitim sürecinde derslere öğrenci katılımının düşüklüğü farklı branşlardaki öğretmenlerle yürütülen çalışmalarda da ortaya çıkan önemli sonuçlardan birisidir. Bayburtlu (2020), Türkçe öğretmenleri ile yürüttüğü çalışmada, öğrencilerin derslere katılım düzeylerinin istenilen seviyede olmadığını belirlerken, Metin, Gürbey ve Çevik (2021) farklı branşlardaki öğretmenlerin uzaktan eğitime ilişkin görüşlerini 
inceledikleri çalışmada öğrenci katılımına yönelik benzer bir tespitte bulunmuştur. Orhan ve Beyhan (2020) da çalışmaları sonucunda bazı öğretmenler öğrencilerin katılım ve katılımlarının beklediklerinden düşük olduğunu, bunun uzaktan eğitimden memnuniyetsizlik yarattığını belirlemişlerdir. Bolliger ve Wasilik (2009), çevrimiçi öğrenme ortamlarında öğretim üyelerinin memnuniyetini etkileyen olası faktörleri öğrenci, öğretmen ve öğretim kurumu ile ilişkili faktörler olarak sınıflandırmıştır. Yürütülen bu çalışmada da öğretmenlerin deneysel çalışmalara yer vermeme nedenleri arasında öğrenci katılımının düşük olması ile ilişkilendirmeleri, bu durumun öğretmen memnuniyetini etkilemesine bağlanabilir. Zan (2021), kimya ve kimya teknolojileri öğretmenleri ile yürüttüğü çalışması sonucunda, bu çalışmanın sonuçlarına benzer şekilde öğretmenlerin öğrencilerin devamsızlığı, isteksizliği, pasif kalmaları ve göz teması kuramama gibi öğrencilerle ilgili sorunlar yaşadıklarını belirlemiştir.

Kimya öğretmenlerinin uzaktan eğitim sürecinde deneysel çalışmalara yer vermeme nedenleri arasında yer alan "kişisel nedenler" teması altındaki açıklamalar kimya öğretmenlerinin online eğitim konusunda hazırlıksız olmaları veya yeterli deneyime sahip olmamaları ile ilişkili olduğu sonucuna ulaşılmıştır. Zan (2021), benzer şekilde kimya öğretmenlerinin teknolojik kullanım yetersizliği ve kendilerinin devamlı ders anlatma zorunda kalmaları ve etkinlikleri yapamama gibi kişisel sorunlar yaşadıkları sonucuna ulaşmıştır. Orhan ve Beyhan (2020) öğretmenlerin BİT bilgi ve becerilerine ve uzaktan eğitim sürecinde uzaktan eğitim teknolojilerini kullanmalarına ilişkin görüşleri ile bunların nasıl deneyimlendiğini inceledikleri çalışmalarında, çalışmaya katılan öğretmenlerin yarısının uzaktan eğitime teknolojik olarak hazır olmadıklarını belirlemişlerdir. Hazır olmama ile ilgili nedenlerden birisinin daha önceden uzaktan eğitim ile ilgili deneyim eksikliği olduğu ve öğretmenlerden bazılarının uzaktan eğitim ile ilgili tedirginlik yaşadıkları sonucuna ulaşılmıştır. Bu çalışmada da öğretmenlerin bu tür bir süreç için ne tür bir eğitim almak istedikleri sorulduğunda çıkan bulgulardan birisi teknolojik destek eğitimi alma isteği olması, Orhan ve Beyhan (2020) tarafından yürütülen çalışmanın bulguları ile örtüşmektedir.

Çalışmada ulaşılan diğer bir sonuç, öğretmenlerin uzaktan eğitim sürecinde deneysel çalışmalara yer vermeme nedenlerinden birisi olarak "teknik nedenler" teması olarak ortaya çıan çevrim içi programların yetersizliği ve bağlanma ile ilgili sorunlar yaşanmasıdır. Bu durum diğer branş öğretmenleri ve kimya öğretmenleri ile yürütülen çalışmalarda da ulaşılan önemli sorunlardan bir tanesi olup Zan (2021), kimya öğretmenlerinin internete yönelik sorunlar yaşadıklarını belirlemiştir. Bayburtlu (2020) Türkçe öğretmenleri ile yürüttüğü çalışmada, benzer şekilde EBA canlı ders uygulamasının bağlantı sorunları ve zaman sınırlaması gibi çeşitli sorunlar yaşasalar da bu sorunların zaman içinde azaldığı sonucuna ulaşmıştır. Diğer taraftan kimya öğretmenlerine OGM Materyal sitesinde (URL-1) yer alan etkileşimli deney videoları hakkında görüşleri sorulduğunda, bu siteyi inceleyenlerin ve derslerinde kullanan öğretmenlerden hiçbiri siteye ulaşma konusunda sorun yaşadığını 
belirtmemiştir. Ancak öğretmenlerin bir kısmının bu siteden haberdar olmadıkları çalışmada ulaşılan diğer bir sonuçtur. Siteyi inceleyen ve derslerinde kullanan öğretmenler, etkileşimli deney videolarını yararlı bulduklarını belirtirken, bazı öğretmenler kitaptaki tüm deneyler için deney videolarının olmamasını eksiklik olarak belirtmişlerdir. Bir öğretmen bu sitede yer alan deneylerde laboratuvar kullarına çok dikkat edilmediğine dikkat çekmiştir.

Öğretmenlerin uzaktan eğitim sürecinde deneysel çalışmaları derslerine nasıl yürüteceklerine yönelik bir eğitim alma istekleri olup olmadığına yönelik çalışmada ulaşılan sonuç, öğretmenlerin \%70'i bu tür bir eğitim konusunda istekliyken \%30'u bu tür bir eğitimi gerekli bulmamasıdır. Çevrimiçi eğitim konusundaki kimya öğretmenlerinin istekleri incelendiğinde, öğretmenlerin çoğunun bu tür bir kurs içeriğinin nasıl olması gerektiğine yönelik isteklerde bulunurken bir kısmının ise kursun hangi şekilde yürütülmesi konusunda isteklerini dile getirdikleri belirlenmiştir. Kursun içeriği ile ilgili istekler incelendiğinde, öğretmenlerin önemli bir kısmının deneysel çalışmaların derslere uygun şekilde nasıl katılacağ 1 ve derslerin planlanmasının nasıl olacağına odaklanırken, bir kısmının deneysel içerik geliştirmeye, teknolojik destek eğitimine veya bu tür deney videolarına nereden ve nasıl ulaşılabileceğine yönelik eğitim içeriklerine odaklandıkları görülür. Bu durum öğretmenlerin kendi eksikleri ile ilgili eğitim isteklerinde bulundukları şeklinde de yorumlanabilir. Çünkü bir dersin planlamasında öğretmenlerin o konudaki deneyimlerin olup olmamasının önemli bir role sahiptir. Kimya öğretmenleri, bilmedikleri veya deneyimlemedikleri uygulamaları derste kullanmanın riskini almak yerine alışılagelmiş yöntemleri tercih ederek bir yerde güvenli limana sığınmaktadırlar. Lloyd, Byrne ve McCoy (2012) öğretmenlerin uzaktan eğitimde öğretmenlik deneyim eksikliğine ve olağan rollerindeki değişime işaret ederek bunların öğretmenleri etkili dersler tasarlama konusunda engelleyebildiğini belirtmiştir. Ayrıca, kimya öğretmenleri ve diğer branş öğretmenleri ile çevrimiçi öğretime yönelik yürütülen çalışmalar öğretmenlerin uzaktan eğitimde daha çok geleneksel yöntemi tercih ettiklerini göstermiştir (Erbil ve diğ., 2021; Zan, 2021). Erbil ve diğ. (2021), uzaktan eğitim sürecinde sınıf öğretmenlerinin izledikleri öğretim yöntem ve tekniklerinin çoğunlukla geleneksel anlayışa dayalı olduğu, anlatım, sorucevap, gösteri, örnek verme gibi geleneksel anlayışta yer alan yöntem-teknikleri kullandıkları sonucuna ulaşılmıştır. Bakioğlu ve Çevik (2020), fen bilimleri öğretmenleri ile yürüttükleri çalışmada yüz yüze öğretim ve uzaktan eğitimde sinıf ortamında öğretim materyali olarak en çok ne kullandıklarını da sorgulamıştır. Öğretmenlerin verdikleri cevaplar arasında yüz yüze öğretimde deney malzemeleri varken, uzaktan eğitim sürecinde kullandıkları öğretim materyalleri arasında deney malzemelerinin yer almadığ

Elde edilen bulgular incelendiğinde kimya öğretmenlerinin uzaktan öğretim sürecinde deneysel çalışmalara derslerinde yer verip vermemelerinin mesleki deneyimleri veya mezun oldukları program ile ilgili olmadığı, sadece görev yapılan okul türü ile kısmen de olsa ilişkili olduğu söylenebilir. Özellikle soru çözümüne 
derslerde daha fazla yer verilmesi gerektiği ve deneysel çalışmaların öğrenciler tarafından zaman kaybı olarak görülmesi nedeniyle derslerde yer verilmediği gibi açıklamaların daha çok fen lisesinde görev yapan öğretmenlerce dile getirildiği belirlenmiştir. Bu durum akademik başarısı yüksek olan ve üniversite sınavı hazırlığının öncelikleri olan öğrenci grubundan oluşmaları ile ilişkilendirilebilir. Diğer taraftan, Millî Eğitim Bakanlığı Ortaöğretim Kurumları Yönetmeliğinde fen liselerinin amacı, fen ve matematik alanlarında öğrencilerin bilim insanı olarak yetiştirilmelerine kaynaklık etmek olduğu şeklinde verilir (Millî Eğitim Bakanlığ1 [MEB], 2013, s. 6). Bu nedenle deneysel çalışmalardaki eksiklik ve çoğunlukla soru çözümü odaklı bir öğretim şekli öğrencilere bilimsel anlamda bir yeterlilik sağlamaktan uzak ve fen liselerinin kuruluş amacı ile de uyumlu olmadığını gösterirken, aynı zamanda son derece kaygı verici bir sonuç olarak da yorumlanabilir. Çünkü ülkemizin fen alanlarında üniversite eğitimlerini sürdürecek ve potansiyel bilim insanı özelliği taşıyabilecek bu öğrencilerin erken yaşlarda bilimsel çalışma yürütme ve buna bağlı becerileri kazanması sağlanamadığı gibi zihinlerinin en açık olduğu zamanlarda birbirinin aynı birçok soru çözümü alıştırması ile uğraşmaları, bu öğrencilerin 21. Yüzyıl becerilerini kazanmadıkları anlamına da gelebilir. Bu durum, eğitimlerini buna göre planlamış ve tür becerilere sahip insan gücü yetiştiren ülkelerle ülkemizin rekabet gücünü zayıflatacağı açıtır. Bu nedenle çalışmada elde edilen bulgulardan yola çıkarak öncelikle gerek yüz yüze laboratuvar ortamında bizzat yaparak yaşayarak ya da sanal ortamda, sanal laboratuvar uygulamaları şeklinde öğrencilerin bizzat deneysel çalışmalarla uğraşacak şekilde derslerin planlanmasına gidilmesi gerekmektedir. Bu imkânların olmaması durumunda öğretmenlerin uygun şekilde etkileşimli deney videolarını derslerinde kullanılarak öğrencilerin bilimsel bir çalışma ortamında yetiştirilmeleri sağlanmalıdır. Diğer taraftan bu çalışmanın bulgularından da görüldüğü gibi ülkemizde ortaöğretim düzeyinde öğrencilerin üniversite sinav hazırlığı her şeyin önüne geçmiş durumdadır. Özellikle akademik başarısı yüksek ve motive öğrencilerin üniversite sınavı kazanma şanslarının daha yüksek olduğu düşüncesi ile bu öğrencilere özellikle üniversiteye hazırlık konusunda öğretim yapılmaktadır. Bu tür bir durumu düzeltmenin yolunun üniversite sınav soru içeriklerinden geçtiği açıtır. PISA sınavlarında ülkemizin sonuçlarının üst sıralarda yer alamaması (MEB, 2015), öğrencilerin PISA soru türlerine aşina olmamaları ile büyük ölçüde ilişkili olduğu söylenebilir. Çünkü üniversite giriş sınavlarında yer alan program odaklı kimya dersi soruları ile öğrencilerin daha çok matematiksel problem çözme becerileri ölçülürken, PISA sınavlarındaki sorular ile öğrencilerin okulda öğrendiklerini ne kadar hatırlayabildiklerinden çok, öğrendiklerini okulda ve okul dışı yaşamlarında kullanabilme yeterliklerinin; karşılaşacakları yeni durumları anlamak, sorunları çözmek, bilmedikleri konularda tahminde bulunmak ve muhakeme yapabilmek için bilgi ve becerilerinden ne ölçüde yararlanabildiklerinin belirlenmesi hedeflenmektedir (MEB, 2011). Bu açıklamalar doğrultusunda Türkiye'de yapılan özellikle TYT sınav mantığına da uygun olması açısından, sayısal problem çözme ötesinde birçok farklı bilimsel süreç becerisi ölçülen sorulara yer 
verilmesi önerilebilir. Böylece kimya öğretmenlerinin sınıf içi öğretimlerinde beceri geliştirici deneysel etkinlere yer vermesi sağlanabilir.

Miglani ve Awadhiya (2017), öğretmenlerin çevrimiçi öğretime hazır bulunuşluklarının uzaktan eğitimin etkin bir şekilde verilmesinde önemli rol oynadığını belirtmişlerdir. Çalışmalarında, katılımcı öğretmenlerin uzaktan eğitim konusundaki deneyimsizlikleri ve bilgi eksiklikleri uzaktan eğitime bakış açılarını belirleyen temel faktörler olabilir; nitelikli uzaktan eğitimin verilebilmesi için öğretmen algılarının geliştirilmesi ve hizmet öncesi eğitim ve hizmet içi eğitim faaliyetlerinde gerekli eğitimlerin verilmesi gerekmektedir. Öğretmenlerin eğitim sürecinde sisteme yakınlığı ve hazır bulunuşluğu öğretim sisteminin önemli bir girdisidir. Öğretmenlerin uzaktan eğitime yönelik olumlu alg1 geliştirmeleri için gerekli teknolojik araç-gereç ve donanım ile bilgi eksiklikleri mümkün olduğunca giderilmesi gerekmektedir. Lloyd vd. (2012) de pedagojik destek ve materyal desteğinin öğretmenlerin performansını artırabileceği ifade etmişlerdir. Çalışma sonuçlarından da görüldüğü gibi öğretmenlerin istedikleri eğitim içeriğinde deney videolarına nasıl erişileceği ve nasıl kullanılacağına yönelik isteklerin yer alması, öğretmenlere etkileşimli deney videoları, sanal laboratuvar uygulamaları, deney simülasyonları ile ilgili kaynak olacak internet siteleri ile bilgi ve benzeri kaynaklar sağlanmalıdır.

Bu noktada kimya öğretmen eğitiminin içeriğinin de bu tür eğitimlere uygun şekilde düzenlenmesinin ne kadar önemli olduğunu bu süreç açık bir şekilde göstermiştir. Yaklaşık dört yıl önce değiştirilen ve tüm ülkedeki eğitim fakülteleri için ortak hale getirilen kimya öğretmenliği programları incelendiğinde, alan derslerinin ve özellikle laboratuvar derslerinin sayısı daha önceki programın yarısına indirilmiş ve bazı derslerin laboratuvar kısımları tamamen kaldırılmıştır. Kimya ve kimya alan eğitimi ve laboratuvar derslerinin toplamı tüm programın \%50'sinin altındadır. Bu durum kimyayı tam anlamıyla öğrenemeyen ve yeterli deneysel çalışma deneyimine sahip olmayan kimya öğretmenlerinin yetiştirilmesi anlamına gelmektedir. Ortaöğretim Kimya Dersi Programlarının içerik kazanımları ve programın deneysel çalışmalara yönelik özel amaçları incelendiğinde, şu anki kimya öğretmenliği programları ile bunları kazandıracak öğretmen yetiştirilmesi zor görünmektedir. $\mathrm{Bu}$ nedenle bu çalışmanın kimya öğretmen eğitimi açısından en önemli önerisi, kimya öğretmeni yetiştiren programların tekrar laboratuvar ders saatleri sayısının arttırılmasıdır.

\section{Etik Beyan}

“Covid-19 Sürecinde Kimya Öğretmenlerinin Derslerinde Deneysel Çalışmalara Yer Verme Durumunun İncelenmesi" başlıklı çalışmanın yazım sürecinde bilimsel, etik ve alıntı kurallarına uyulmuş; toplanan veriler üzerinde herhangi bir tahrifat yapılmamış ve bu çalışma herhangi başka bir akademik yayın ortamına değerlendirme için gönderilmemiştir. 


\section{Kaynaklar}

Akaygün, S., Elmas, R., Kara, H., Karataş, F. Ö., \& Yıldırım, G. (2016). Fen lisesi kimya öğretmenlerinden bir yansıtma: Güncellenen kimya öğretim programı ile ilgili görüşler. Erzincan Üniversitesi Eğitim Fakültesi Dergisi, 18(2), 737-770. https://doi.org/10.17556/jef.36724

Akkuş, H., \& Kadayıfçı, H. (2007). “Laboratuvar kullanımı” konulu hizmet-içi eğitim kursu ile ilgili bir değerlendirme. Gü, Gazi Eğitim Fakültesi Dergisi, 27(1), 179-193.

Aydin, E., \& Erol, S. (2021). The views of Turkish language teachers on distance education and digital literacy during Covid-19 Pandemic. International Journal of Education and Literacy Studies, 9(1), 60-71. http://dx.doi.org/10.7575/aiac.ijels.v.9n.1p.60

Bakioğlu, B. \& Çevik, M. (2020). COVID-19 pandemisi sürecinde fen bilimleri öğretmenlerinin uzaktan eğitime ilişkin görüşleri. Turkish Studies, 15(4), 109-129. https://dx.doi.org/10.7827/TurkishStudies.43502

Bayburtlu, Y.S. (2020). Covid-19 pandemi dönemi uzaktan eğitim sürecinde öğretmen görüşlerine göre Türkçe eğitimi. Turkish Studies, 15(4), 131-151. https://dx.doi.org/10.7827/TurkishStudies.44460

Berg, B. L. (1998). Qualitative research method for the social sciences, 3d ed. Boston, MA Allyn \& Bacon.

Bolliger, D. U., \& Wasilik, O. (2009). Factors influencing faculty satisfaction with online teaching and learning in higher education. Distance Education, 30(1), 103-116.

Bozkurt, A. (2020). Koronavirüs (Covid-19) pandemi süreci ve pandemi sonrası dünyada eğitime yönelik değerlendirmeler: Yeni normal ve yeni eğitim paradigması. Açıköğretim Uygulamaları ve Araştırmaları Dergisi, 6(3), 112-142.

Büyüköztürk, Ş., Kılıç Çakmak, E., Akgün, Ö. E., Karadeniz, Ş., \& Demirel, F. (2009). Bilimsel Araştırma Yöntemleri. 3. Baskı, Ankara, Pegem Akademi.

Çakın, M., \& Akyavuz, E. K. (2020). Covid-19 süreci ve eğitime yansıması: öğretmen görüşlerinin incelenmesi. International Journal of Social Sciences and Education Research, 6(2), 165-186.

Demir, E. (2021). 2018 Ortaöğretim Kimya Dersi Öğretim Programı ve 2018 Ortaöğretim Fen Lisesi Kimya Dersi Öğretim Programı'nın temel öğeler açısından karşılaştırılması. Journal of Turkish Chemical Society Section C: Chemistry Education (JOTCS-C), 6(2), 171-208.

Demir, E., Gacanoğlu, Ş., \& Nakiboğlu, C. (2017). 2013 Kimya dersi öğretim programı"na yönelik öğretmen görüşleri doğrultusunda 2017 kimya dersi öğretim programı"nın değerlendirilmesi. Journal of Turkish Chemical Society Section: C, 2(2), 135-184.

Erbil, D. G., Demir, E. \& Armağan Erbil, B. (2021). Pandemi sürecinde uzaktan eğitime yönelik sınıf öğretmenlerinin görüşlerinin incelenmesi. Turkish Studies Education, 16(3), 1473-1493. https://dx.doi.org/10.47423/TurkishStudies.49745

Ersoy, H. (2019). Durum Çalışması. İçinde Y. Özden., \& Durdu, L. (Ed.), Eğtimde üretim tabamlı çalışmalar için nitel araştırma yöntemleri (ss. 4-5). Ankara: Anı Yayınevi. 
Feyzioğlu, B. (2014). Dokuzuncu sınıf kimya dersi öğretim programına yönelik öğretmen görüşleri: Aydın ili örneği. Ondokuz Mayıs Üniversitesi Ĕ̆itim Fakültesi Dergisi, 33(1), 231-260.

Karakuş, N., Ucuzsatar, N., Karacaoğlu, M. Ö., Esendemir, N., \& Bayraktar, D. (2020). Türkçe öğretmeni adaylarının uzaktan eğitime yönelik görüşleri. RumeliDE Dil ve Edebiyat Araştırmaları Dergisi, (19), 220-241. https://dx.doi.org/10.29000/rumelide.752297

Lloyd, S. A., Byrne, M. M., \& McCoy, T. S. (2012). Faculty-perceived barriers of online education. Journal of Online Learning and Teaching, 8(1), 1-12.

Milli Eğitim Bakanlığı (MEB) (2011). PISA Türkiye. Yenilik ve Eğitim Teknolojileri Genel Müdürlüğ̈̈, Ankara.

Milli Eğitim Bakanlığ1 (MEB) (2013). Milli Eğitim Bakanlığı Ortaöğretim Kurumları Yönetmeliği. Resmî Gazete (28758).

Milli Eğitim Bakanlığı (MEB) (2015). PISA 2015 Ulusal Raporu. Ölçme Değerlendirme ve Sınav Hizmetleri Genel Müdürlüğü, Ankara.

Millî Eğitim Bakanlığ1 (MEB) (2018a). Ortaöğretim Kimya Dersi (9, 10, 11 ve 12. sınıflar) Öğretim Programı. Talim ve Terbiye Kurulu Başkanlığı.

Millî Eğitim Bakanlığı (MEB) (2018a). Ortaöğretim Fen Lisesi Kimya Dersi (9, 10, 11 ve 12. sinıflar) Öğretim Programı. Talim ve Terbiye Kurulu Başkanlığı.

Metin, M., Gürbey, S. \& Çevik, A. (2021). Covid-19 Pandemi sürecinde uzaktan eğitime yönelik öğretmen görüşleri. Maarif Mektepleri Uluslararası Eğitim Bilimleri Dergisi, 5(1), 6689. https://doi.org/10.46762/mamulebd.881284

Miglani, A., \& Awadhiya, A. K. (2017). Mobile learning: Readiness and perceptions of teachers of open universities of commonwealth Asia. Journal of Learning and Development $J L 4 D, 4(1), 58-71$.

Miles, M. B., \& Huberman, A. M. (1994). Qualitative data analysis: An expanded sourcebook. Sage.

Morgil, İ., Seyhan, H. G., \& Seçken, N. (2009). Proje destekli kimya laboratuvarı uygulamalarının bazı bilişsel ve duyuşsal alan bileşenlerine etkisi. Journal of Turkish Science Education, 6(1), 89-107.

Nakiboğlu, C., \& Sarıkaya, Ş. (1999). Ortaöğretim kurumlarında kimya derslerinde görevli öğretmenlerin laboratuvarda yararlanma durumunun değerlendirilmesi. D.E.Ü Buca Eğitim Fakültesi Dergisi Özel Sayı, 11, 395-405.

Nakiboğlu, C., \& Sarıkaya, Ş. (2000). Kimya öğretmenlerinin derslerinde laboratuvar kullanmalarına mezun oldukları programın etkisi. Gazi Üniversitesi Kastamonu Ĕ̆itim Dergisi, 8(1), 95-106.

Nakiboğlu, C. (2021). Fen lisesi kimya ders kitaplarındaki deneylerin 2018 Yılı Fen Lisesi Kimya Dersi Öğretim Programı'nın deneysel çalışmaya yönelik amacı açısından analizi. Journal of Turkish Chemical Society Section C: Chemistry Education (JOTCS-C), 6(2), 209-240.

Orhan, G., \& Beyhan, Ö. (2020). Teachers' perceptıons and teaching experıences on distance education through synchronous video conferencing during Covid-19 pandemic. Social Sciences and Education Research Review 7(1), 18-44. 
Özden, M. (2007). Kimya öğretmenlerinin kimya öğretiminde karşılaştıkları sorunların nitel ve nicel yönden değerlendirilmesi: Adıyaman ve Malatya illeri örneği. Pamukkale Üniversitesi Eğitim Fakültesi Dergisi, 22(2), 40-53

Özmen, H. (2004). Kimya-1, 2 ders kitaplarındaki deneylerin uygulanabilirlik düzeylerine ve laboratuvar kullanımına yönelik öğretmen görüşleri. Hasan Ali Yücel Eğilim Fakültesi Dergisi, 1, 11-27.

Srisawasdi, N. I. W. A. T. (2014). Developing technological pedagogical content knowledge in using computerized science laboratory environment: An arrangement for science teacher education program. Research \& Practice in Technology Enhanced Learning, 9(1), 123-143.

Zan, N. (2021). Kimya öğretmenlerinin; Covid-19 sürecinde uzaktan eğitim uygulamaları hakkında görüşleri. Journal of Turkish Chemical Society Section C: Chemistry Education (JOTCS-C), 6(2), 241-284. 